\title{
A PAISAGEM URBANA DAS CIDADES HISPANO-AMERICANAS E SUAS TRANSFORMAÇÕES NO SÉCULO XVIII
}

\section{THE URBAN LANDSCAPE OF HISPANIC-AMERICAN CITIES AND THEIR} TRANSFORMATIONS IN THE 18TH CENTURY

\author{
Rodrigo Espinha Baeta \\ Universidade Federal da Bahia \\ rodrigo.espinha.baeta@gmail.com
}

\section{Resumo}

Quando se analisa a conformação dos núcleos urbanos fundados pelos espanhóis nas Índias Ocidentais a partir do início do século XVI, desponta o impressionante processo de elaboração de uma tipologia regular de cidade: uma tendência de ordenação referente ao plano gerador que teria sido repetida inúmeras vezes, nas mais diversas regiões do vasto território sob o domínio da metrópole peninsular - culminando na realização de um modelo de cidade que apresentaria uma organização absolutamente cartesiana. Em oposição aos primeiros dois séculos de colonização, o cenário urbano nos setecentos deveria almejar a uma paisagem urbana dramática - aliada a poética barroca -, dificilmente expressada na engessada cidade em damero. Logo, as cidades ordenadas deveriam contar com intervenções - de teor urbanístico, mas especialmente de escala arquitetônica - que atuassem "contra" a quadrícula. Ou seja, através da corrupção do esquema rígido da traza hispano-americana e da inclusão de exuberantes exemplares da arquitetura religiosa, os assentamentos coloniais poderiam ser transfigurados em prol da exaltação de acontecimentos cenograficamente dramáticos.

\section{Palavras-chave}

América hispânica. Paisagem urbana. Barroco. Cidade regular. Arquitetura religiosa.

\begin{abstract}
When analysing the conformation of the cities founded by the Spaniards in the America from the beginning of the sixteenth century, the impressive process of elaborating a regular typology of the city is latent: a tendency of ordering referring to the plan that generated human settlements repeated over and over again, in the most diverse regions of the vast territory under the dominion of the peninsular metropolis - culminating in the realization of a model of city that would present an absolutely Cartesian organization. In opposition to the first two centuries of
\end{abstract}

(c) Urbana: Rev. Eletrônica Cent. Interdiscip. Estud. Cid. Campinas, SP V.10, n.1 [18] p.54-103 jan./mai. 2018 
colonization, the urban scene in the Seventeenth century aim at a dramatic urban landscape allied with baroque poetics -, hardly expressed in the damero. Therefore, ordered cities should accept on interventions - urbanistic, but especially architectural scale - that act "against" the grid. That is, through the corruption of the rigid scheme of the Hispano-American traza and the inclusion of exuberant examples of religious architecture, colonial settlements could be transfigured for the sake of exaltation of scenographically dramatic events.

\section{Keywords}

Hispanic America. Urban landscape. Baroque. Regular city. Religious architecture.

\section{Introdução}

Quando se analisa a conformação dos núcleos urbanos fundados pelos espanhóis nas Índias Ocidentais durante o período colonial fica latente o impressionante processo de desenvolvimento de uma tipologia regular de cidade: uma tendência de ordenação referente ao plano gerador dos assentamentos humanos criados - e algumas vezes sobrepostos a antigos aglomerados pré-colombianos - que teria sido repetida inúmeras vezes, nas mais diversas regiões do vastíssimo território sob o domínio da metrópole peninsular (Figura 1). Este processo seria fruto de um projeto de urbanização territorial aparentemente inédito, especialmente ao se considerar a monumental extensão das terras ocupadas e conquistadas nas Américas por súditos da coroa espanhola, bem como o inigualável número de organismos urbanos levantados em um período tão curto de tempo: só no século XVI, mais de 200 cidades teriam sido fundadas no Caribe, na Mesoamérica, na América Central e nas áreas não lusitanas da parte meridional do grande continente (especialmente em torno da Cordilheira dos Andes e nas imediações do Rio da Prata). Segundo atestariam os arquitetos e críticos espanhóis, Fernando Chueca Goitia e Leopoldo Torres Balbás, não houve na história da humanidade uma ação tão extensa e rápida de urbanização comandada por uma única nação, por um único governo:

A obra de criação urbana, realizada entre os séculos XVI e XIX, foi enorme. Nenhum outro povo levou a cabo, neste aspecto, nada que sequer de longe possa ser comparado a esta iniciativa. No continente recém descoberto pouquíssimas vezes foi aproveitada alguma cidade pré-colombiana; a imensa maioria dos núcleos urbanos foram de nova fundação. No transcurso da história os povos conquistadores sempre se instalaram nas cidades que tomavam. Na América hispânica tiveram que partir do zero

(c) Urbana: Rev. Eletrônica Cent. Interdiscip. Estud. Cid. Campinas, SP v.10, n.1 [18] p.54-103 jan./mai. 2018 
e criar totalmente, sobre terras, na maioria das vezes, sem cultivo, cidades que surgiram como por arte da magia em lugares despovoados. (CHUECA GOITIA, TORRES BALBÁS, 1981, p. VII, tradução nossa)

Para isso, segundo afirmaria o Professor Alberto Nicolini (2005, p. 29), desde Santo Domingo (a primeira cidade fundada nas Américas pelos espanhóis), o delineamento regular dos núcleos urbanos aspiraria, gradativamente, a um esquema cada vez mais rigoroso, culminando na realização de um modelo que apresentaria uma organização absolutamente cartesiana (Figura 2): a cidade projetada de forma quadrangular, com quarteirões e a praça pincipal quadrados, assim como lotes urbanos também quadrangulares - fruto da divisão das quadras em quatro solares de idênticas dimensões (Figura 3).

Contudo, um lento processo de ocupação e desenvolvimento viria a ocorrer nas cidades coloniais, após as suas fundações (geralmente ocorridas no século XVI). Em alguns assentamentos, estrategicamente implantados, o espaço urbano se consolidaria de maneira um pouco mais célere; e em outros, menos significativos e prósperos, de forma muito vagarosa. 0 ato de criação, bem como o delineamento prévio dos núcleos urbanos, particularmente aqueles projetados através de um design que tenderia a regularidade - aqueles concebidos por meio de uma traza que fosse efetivamente ordenadora -, seria o primeiro instante que marcaria o intricado processo de constituição da estrutura e da paisagem urbana.

Indubitavelmente, o desenho elaborado com antecedência à implantação do organismo urbano viria a ser uma ocasião de enorme gravidade para a definição do cenário que se estabeleceria na vivência do ambiente citadino - já que, como diria o arquiteto e crítico italiano Aldo Rossi (2006, p. 56), o plano não seria apenas um dos mais eficientes organismos estruturadores da cidade, mas, especialmente, um dos elementos que apresentaria maior disposição em permanecer inalterado no futuro desenvolvimento do ambiente urbano.

Não obstante, o projeto de distribuição e estruturação das vias e solares deveria tomar forma física, e mesmo a simples implantação da traza não garantiria a sua consolidação como um núcleo vigoroso e animado que funcionasse efetivamente como uma cidade. Deste modo, ao contrário do que aconteceria na maioria dos burgos medievais do continente europeu - que frequentemente passariam por um crescimento orgânico, sem a existência de um design global previamente elaborado -, para os núcleos mais importantes da América espanhola, os primeiros habitantes que viriam a ocupar seu espaço urbano - os conquistadores que teriam alcançado e dominado os povos da região - veriam nascer a estrutura viária da cidade balizada pelo seu plano bidimensional antes mesmo de ser habitada. Por isso, nos primórdios 
da colonização, a força do design regulador seria imediatamente sentida em alguns aspectos essenciais para o desenvolvimento das cidades - em situações que seriam totalmente incomuns se comparadas à realidade do agenciamento das urbes europeias. Tanto os assentamentos principais - as capitais senhoriais dos virreinatos, das audiencias, das gobernaciones -, como os núcleos urbanos menos representativos, teriam seu processo de desenvolvimento iniciado pela ocupação dos lotes provenientes do parcelamento das quadras que conformavam o perímetro da plaza mayor, ou daquelas que estariam distribuídas no entorno imediato a ela. Os solares destinados à igreja matriz ou à catedral, aos edifícios ligados à administração regional ou municipal e as parcelas de terreno direcionadas aos primeiros e aos mais respeitáveis conquistadores, estariam, invariavelmente, locados em volta da plaza de armas, e nas quadras nas suas proximidades (SALCEDO, 1990, p. 46). Por outro lado, quanto mais afastadas fossem em relação à praça principal, quanto mais distantes do centro dominante da cidade estivessem as quadras previstas no plano inicial, menos disputados seriam os solares que as constituiriam.

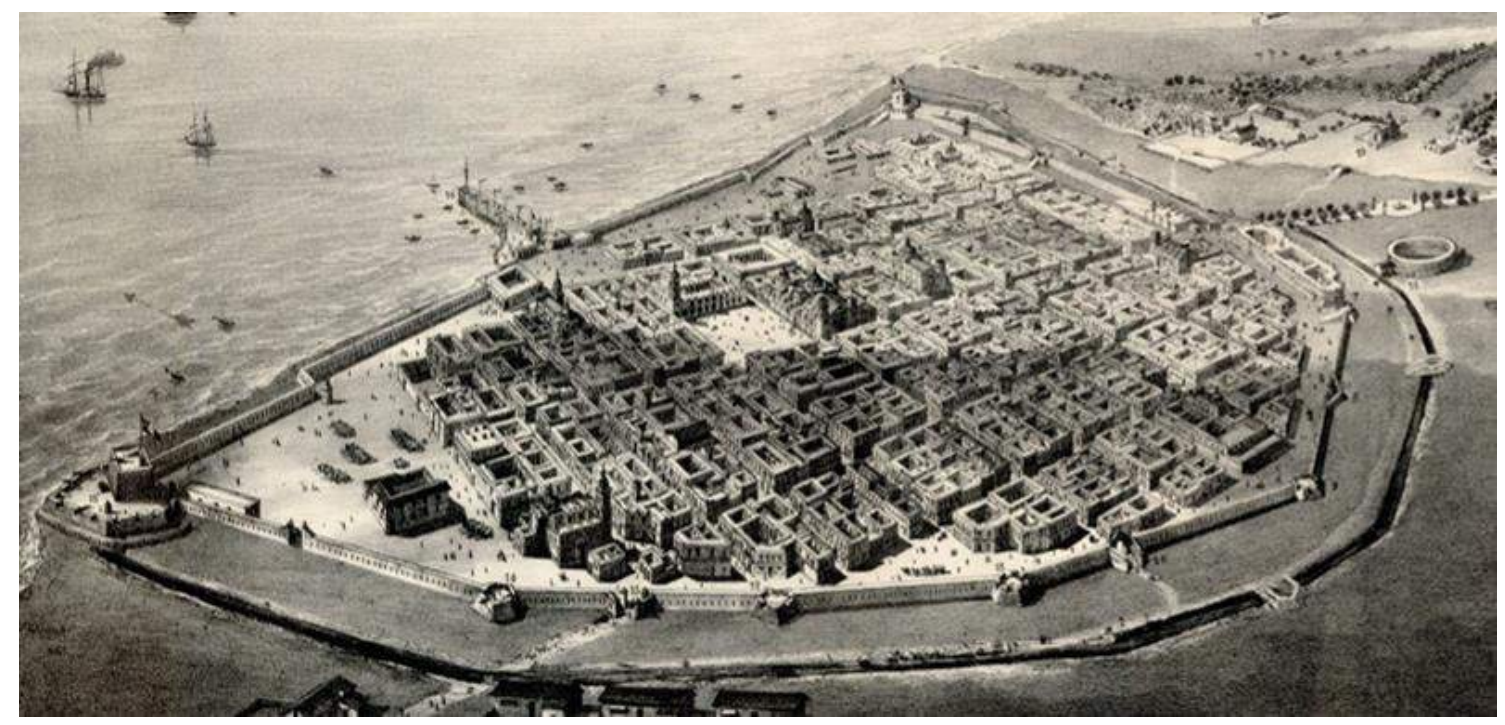

Figura 1 - Litografia feita em 1846, pelo desenhista e pintor mexicano Casimiro de Castro (1826-1889), mostrando a cidade de Veracruz (México) - fundada em 1519. Fonte: http://www.lib.utexas.edu/benson/historicmaps/maps17.htm Acesso em 13 de abril de 2011. University of Texas Libraries. 


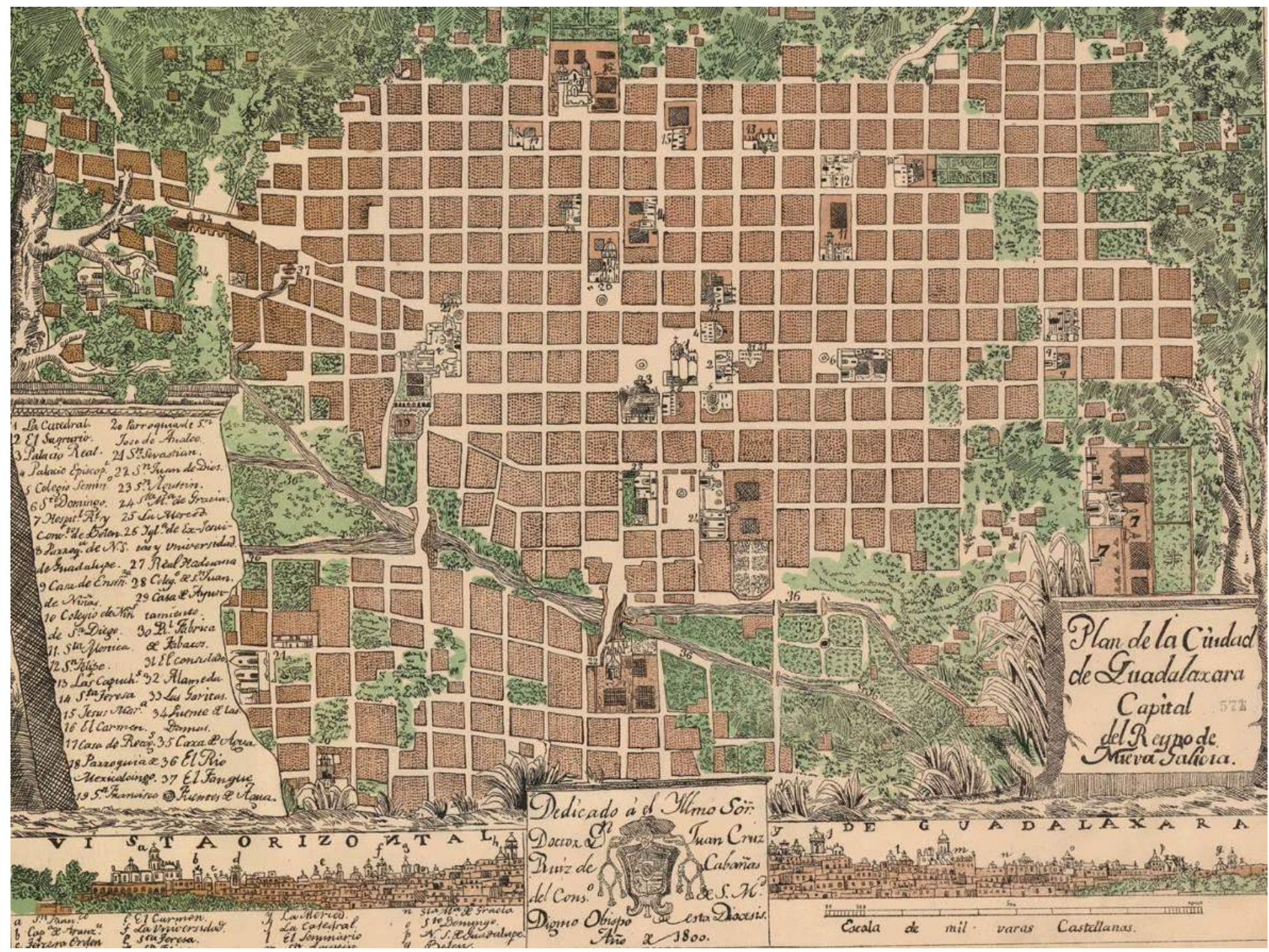

Figura 2 - Plan de la Ciudad de Guadalaxara Capital del Reyno de Nueva Galicia (México). Confeccionado no ano de 1800 - cidade fundada oficialmente em 1542. Fonte: http://www.lib.utexas.edu/benson/historicmaps/maps5.html Acesso em 13 de abril de 2011. University of Texas Libraries. 


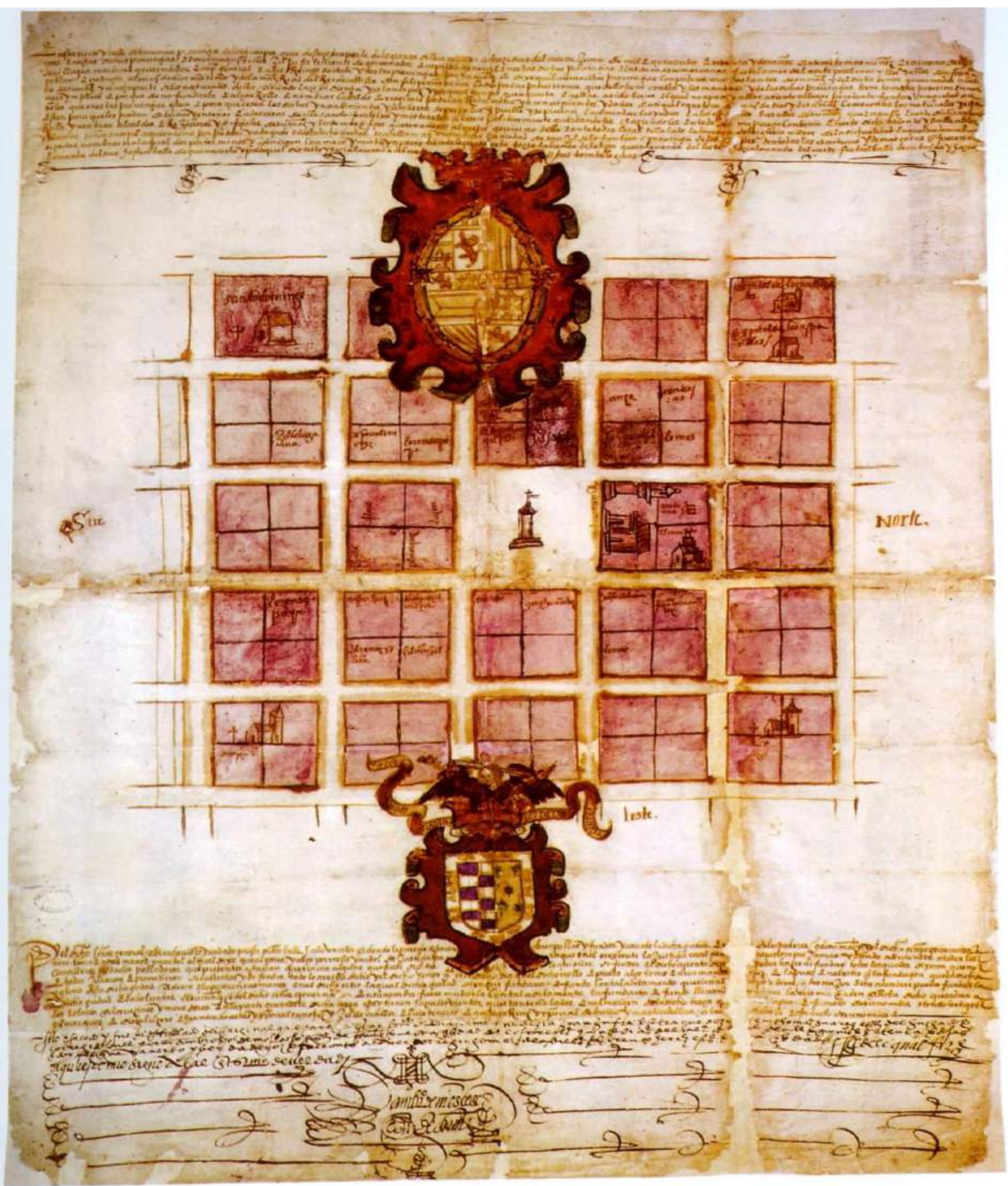

Figura 3 - Plano de la fundación de San Juan de la Frontera, de la ciudad del Reyno de Chile - atualmente na Argentina. Plano assinado em 1562. Fonte: Van Doesburg (2007, v. 1, p. 75). 


\section{A baixa densidade da ocupação do tecido urbano nos dois primeiros séculos da colonização}

Logo, em muitas cidades coloniais hispano-americanas, inúmeros quarteirões assentados nas cercanias do limite entre a estrutura viária constituída e o ambiente rural fronteiriço estariam ainda desocupados ao final do século XVII, e assim permaneceriam por muitas décadas - situação totalmente improvável em uma cidade do Velho Continente, justamente em função do natural crescimento centrífugo e orgânico que a estrutura urbana das cidades europeias sofreria com o passar dos séculos. Segundo José Luis Romero:

Se a traza foi um projeto, seu alcance e distribuição revelam a perspectiva que os fundadores descobriam para as novas cidades. A certas capitais - México, Lima, Buenos Aires - foi atribuída uma área que ultrapassava uma centena de blocos; mas a grande maioria das cidades tinha cerca de vinte e cinco e, tanto umas como outras levaram muito tempo para alcançar uma edificação compacta, fora do centro da cidade. No fim do século XVII ou no início do século XVIII muito poucas tinham ultrapassado esses limites, mesmo que tivessem aparecido algumas formações suburbanas irregulares. (ROMERO, 2007, p. 100 - tradução nossa)

Por outro lado, mesmo nas áreas centrais das influentes capitais coloniais, nos núcleos urbanos estrategicamente implantados, ou nas cidades que, por algum motivo comércio, porto, mineração - alcançariam, rapidamente, significativa prosperidade econômica, a densidade da massa construída em relação a traza propriamente dita, em relação à armação viária rasgada no primeiro instante de edificação do complexo urbano, seria invariavelmente baixa até o avançar do século XVII. O motivo deste caráter rarefeito estaria, em grande parte, relacionado à incrível dimensão que o organismo urbano desnudo já acolheria por ocasião da implantação da estrutura viária e de sua divisão fundiária. O tamanho das quadras, a largura das vias e principalmente a extensão dos solares seriam particularmente colossais - se confrontados à contemporânea realidade das cidades europeias. Por exemplo, para o assentamento da cidade de Lima, a antiga Ciudad de los Reyes, capital do vice-reinado do Peru, fundada por Pizarro em 1535, seria estabelecida uma traza formada por uma quadrícula perfeita na qual as quadras possuiriam 450 pés de lado (cerca de 150 metros) e as vias contariam com 40 pés de largura (por volta de 13 metros). Estas dimensões seriam repetidas, com pequenas variações, em dezenas de núcleos urbanos criados a posteriori em diversos territórios do virreinato peruano, particularmente em 
cidades fundadas na região do Cone Sul americano.

Entretanto, a baixa densidade, consequência da ocupação rarefeita do ambiente urbano, estaria mais vinculada ainda ao parcelamento inicial do solo a que estariam submetidos os assentamentos. Na verdade, a cidade dos conquistadores sempre teria seus quarteirões divididos em poucos lotes, sendo que a prática mais comum para as urbes ligadas ao modelo mais rígido de desenho viário se estabilizaria na decomposição das quadras em apenas quatro solares - o que, em uma cidade com quarteirões de 150 metros de lado, definiria a existência de terrenos de 75 por 75 metros de lado. É lógico que, mesmo reconhecendo a presença inevitável, no centro urbanizado, das imponentes estruturas dos edifícios religiosos - catedrais, palácios arquiepiscopais, igrejas maiores, igrejas paroquiais, conventos, monastérios, hospitais - e das monumentais construções ligadas ao poder da metrópole ou da colônia - palácios de governo, cabildos, ayuntamientos, municipalidades, cárceres -, e mesmo admitindo que pudesse existir uma situação sui generis em que todos os lotes destinados aos primeiros habitantes estivessem tomados, acolhendo devidamente as casas das personalidades mais influentes das senhoriais cidades projetadas para os espanhóis, a densidade construtiva do núcleo urbano seria mínima se comparada a das cidades europeias, pois, com exceção dos grandes monumentos, as construções civis ocupariam apenas uma reduzida porção dos solares.

Na verdade, a casa-huerta privada (MATTOS-CARDENAS, 2004, p. 80), diluída na imensa área dos terrenos destinados aos fundadores, poderia estar locada na esquina das quadras, construída alinhada com a via no meio do solar, ou mesmo levantada para dentro do extenso lote: independentemente disso, a massa edificada do quarteirão contaria, invariavelmente, com uma ínfima densidade construtiva e, consequentemente, com uma baixíssima densidade populacional (Figuras 4 e 5 ).

Portanto, em um primeiro momento, nas longas, largas e retilíneas vias que conformavam a estrutura da cidade virreinal, os panoramas retirados das vastas ruas panoramas nos quais os pontos de fuga se perderiam no vazio resultante da dissolução das vias nas fronteiras do organismo urbano - não apresentariam, contraditoriamente, uma marcada força perspectiva. Nas densas e ancestrais cidades europeias, as poderosas "paredes" formadas pelas fachadas contíguas das altas edificações, alinhadas nas estreitas e contínuas ruas, produziriam aquele típico e aprazível efeito direcional - um sentimento de acolhimento resultante do caráter fechado dos caminhos, retilíneos ou tortuosos, que naturalmente se formavam no interior do organismo urbano. Já nas cidades americanas, a inexistência fatal de uma sequência ininterrupta de edifícios geminados, alinhados com a via, decretaria que, 
proporcionalmente, haveria muito mais espaços vazios do que massa construída na apreensão em profundidade das ruas. A presença das poucas e baixas edificações levantadas nos dois lados dos amplos e largos logradouros, bem como a existência frequente de lacunas oriundas dos inúmeros cruzamentos rasgados em toda a extensão das ruas, tornariam os encaminhamentos perspectivos por demais frágeis e rarefeitos.

Neste contexto, tornar-se-ia explícita a força do plano bidimensional, gerador da distribuição viária do organismo urbano, como elemento não só definidor da estrutura das cidades coloniais, mas também como organismo mais significativo para a construção da paisagem dos núcleos hispano-americanos, pelo menos durante o século XVI. Mesmo quando resoluções urbanísticas regionais ou municipais viriam a exigir o fechamento das áreas livres dos grandes solares através da construção de muros levantados no perímetro exterior das quadras, ou seja, na testada dos lotes (NICOLINI, 1997), a impressão capturada no interior do núcleo urbano seria a de que o plano viário, com a sua regularidade e extensão, "devoraria" implacavelmente a apreciação da paisagem tridimensional do ambiente citadino (Figuras 6 e 7). Assim, a imagem retirada dos flancos das vias, alinhamentos marcados pela presença contínua dos baixos muros, pontuados por poucas edificações, ou por escassas portadas trabalhadas para distinguir a entrada das casas construídas nos interiores dos lotes, continuaria francamente diluída, em termos proporcionais, pela imperativa largura e extensão das vias, sublinhando a força da traza originária sobre a arquitetura, sobre o ambiente tridimensional na percepção do espaço urbano. 


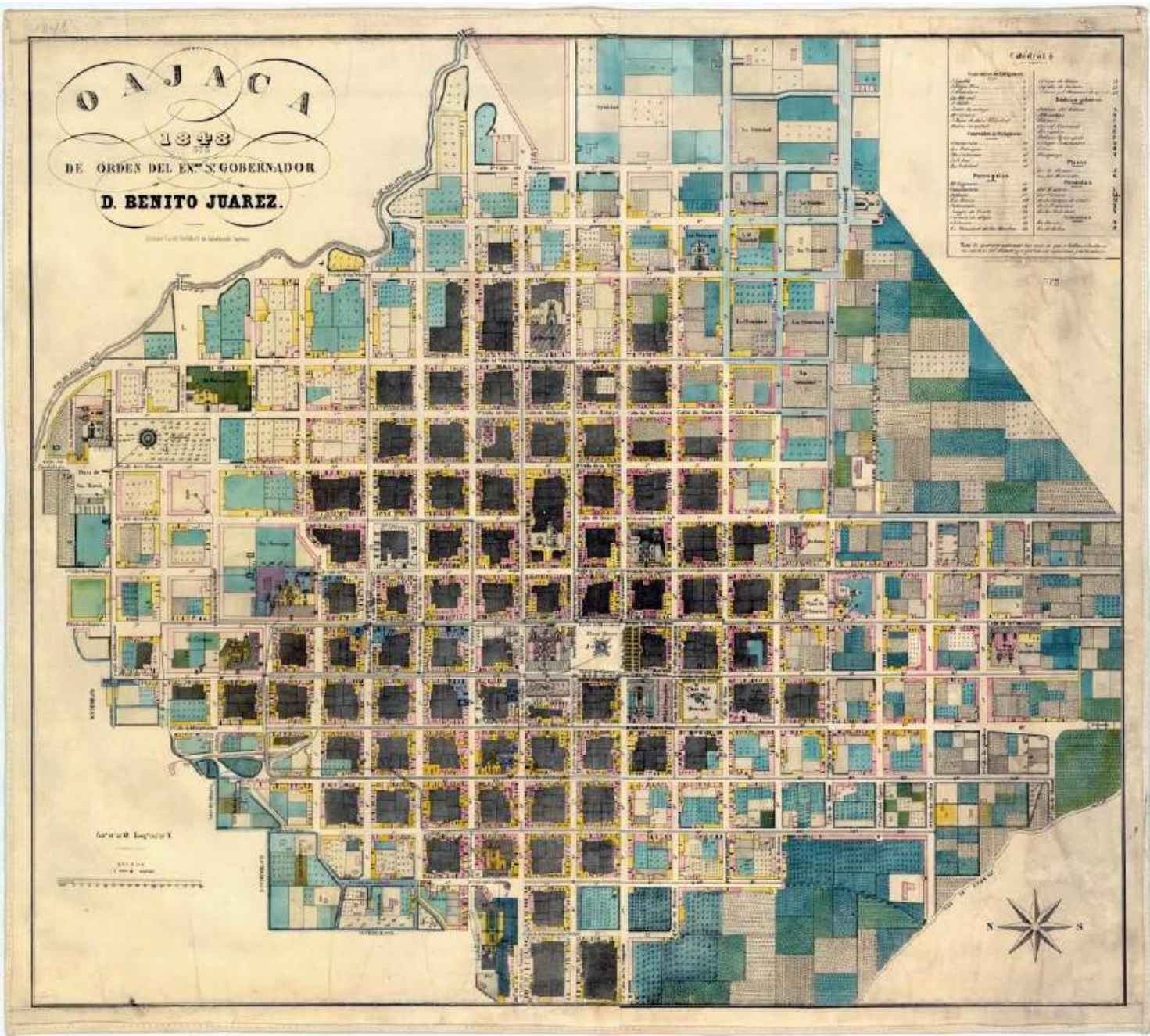

Figura 4 - Plano de Oaxaca (México) de 1843. A planta revelaria que, ainda no século XIX, grande parte da quadrícula regular implantada a partir de 1521 estaria desocupada, lançada na zona rural fronteiriça.

Fonte: http://www.lib.utexas.edu/benson/historicmaps/maps20.html Acessado em 13 de abril de 2011. University of Texas Libraries. 


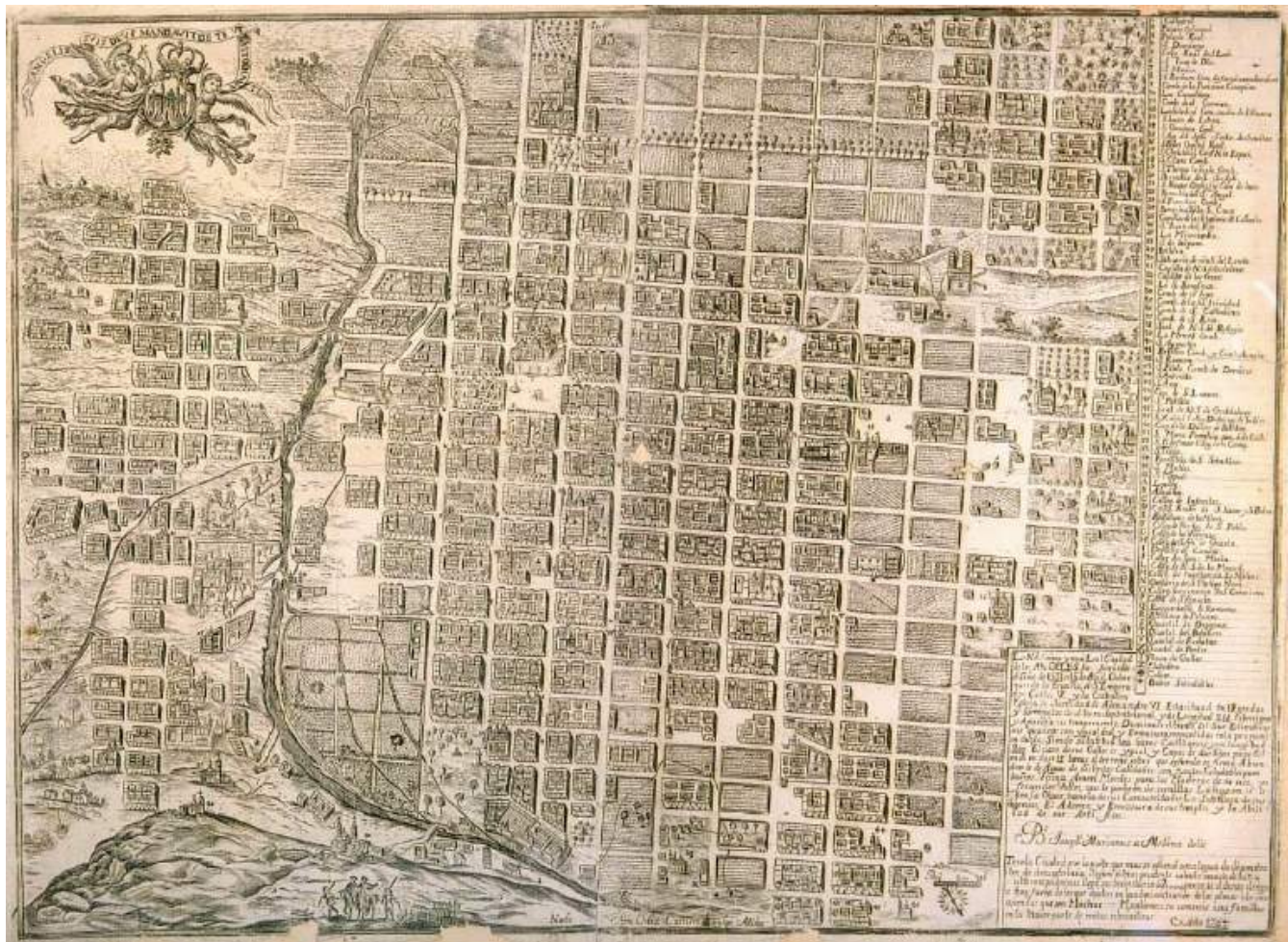

Figura 5 - Plano de Puebla (México) de 1754, elaborado por Joseph Marianus, mostrando os quarteirões retangulares ainda desocupados em meados do século XVIII, nas proximidades da Plaza Mayor. A cidade foi fundada em 1531.

Fonte: Allende Carrera (2006, p. 109).

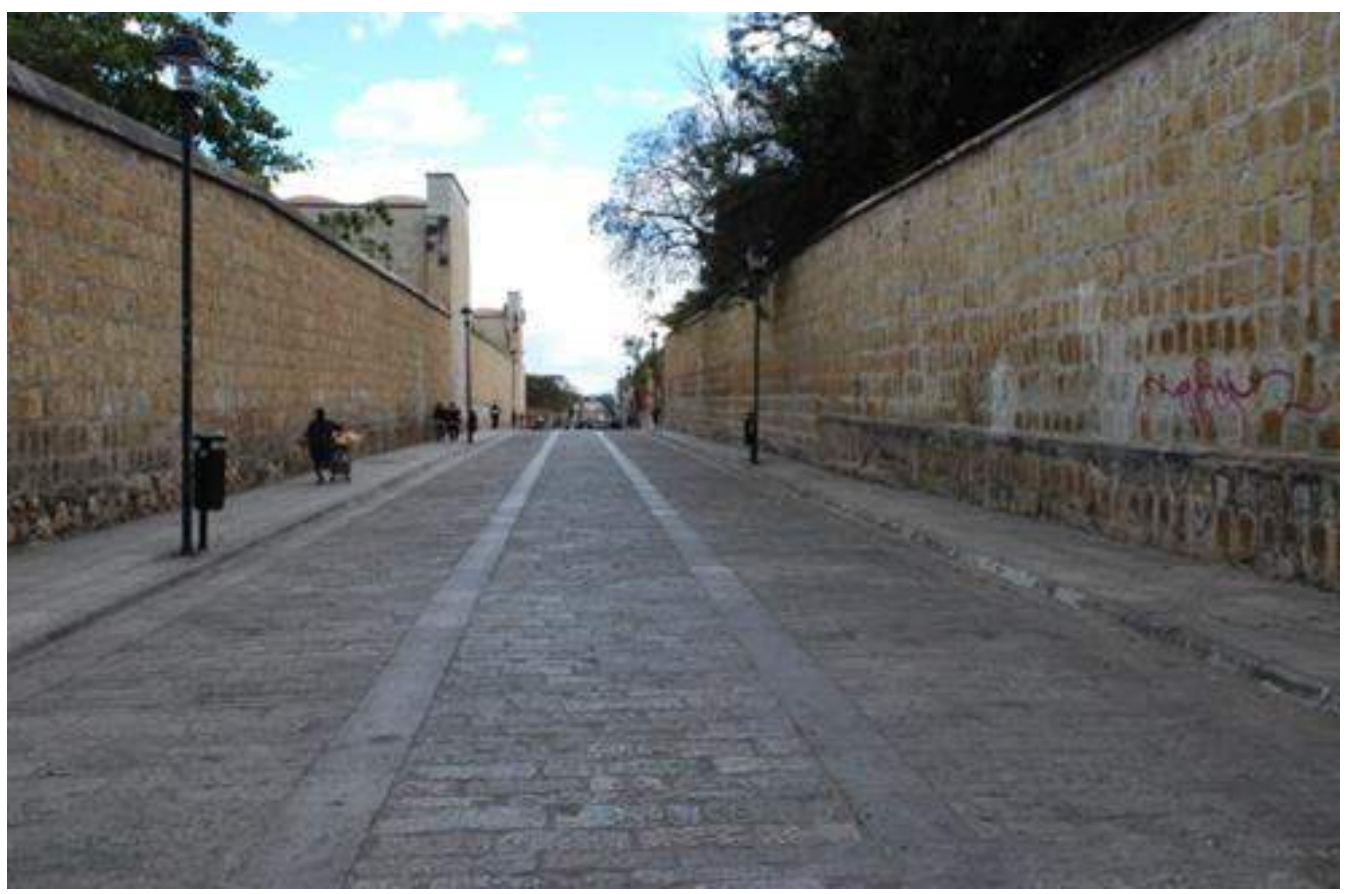

Figura 6 - Via de Oaxaca, nas proximidades do Convento de Santo Domingo. Atualmente ainda é possível perceber seguimentos de rua cujas testadas são preenchidas com muros. Fonte: Fotografia do autor, 2009. 
DOI: $10.20396 /$ urbana.v10i1.8651022
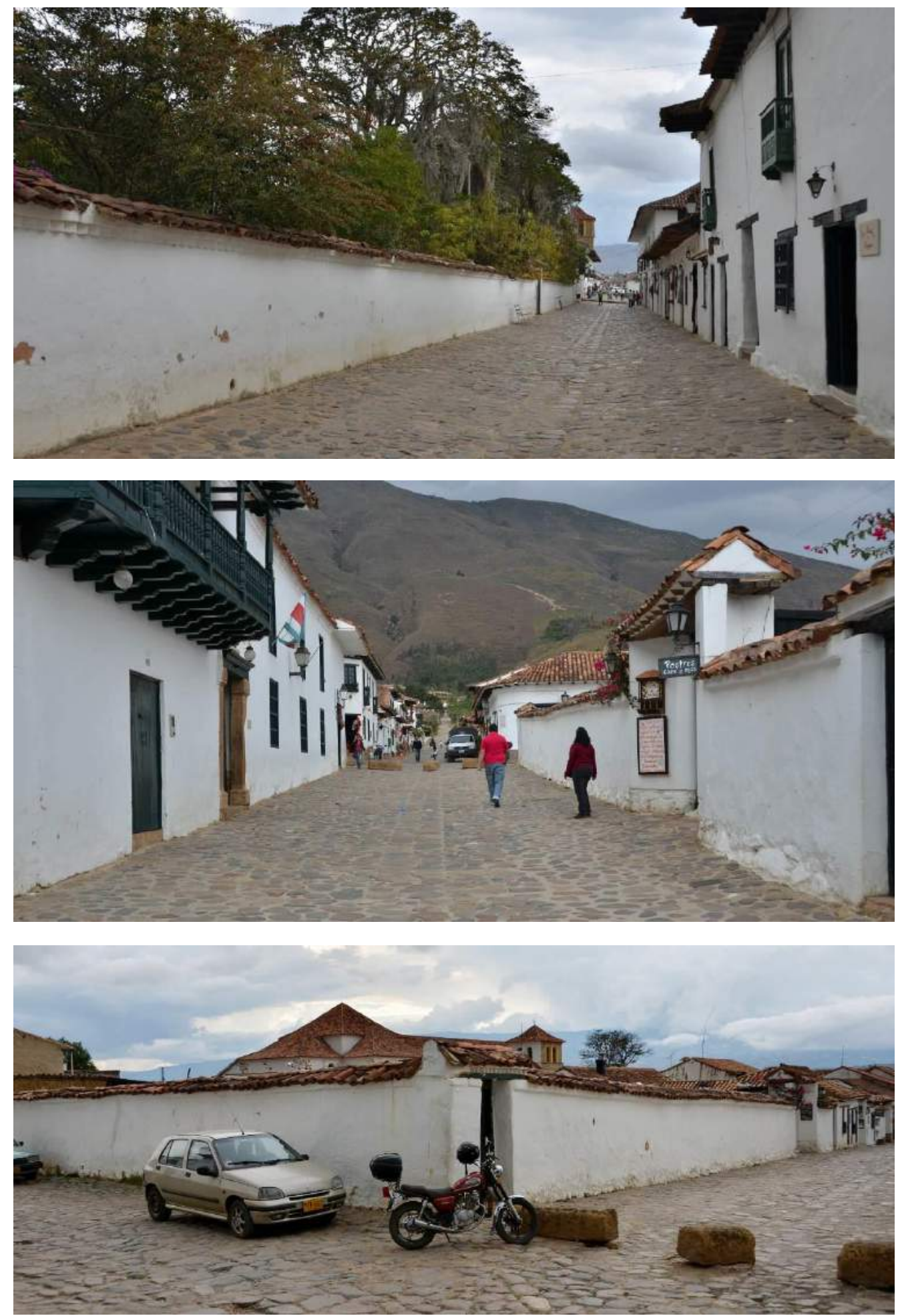

Figura 7 - Três panoramas de logradouros da Villa de Leyva (Colômbia), fundada em 1572. Mais de quatrocentos e cinquenta anos após a fundação do núcleo urbano nota-se, quase adjacente à plaza mayor, a presença dos muros para alinhar as testadas dos grandes lotes desocupados com as vias.

Fonte: Fotografias do autor, 2013. 


\section{Estrutura e paisagem nas cidades hispano-americanas no século XVI: a plaza mayor}

Contudo, seria a plaza mayor o elemento urbanístico que assinalaria, fatalmente, o caráter de centralidade que a grande maioria das cidades hispano-americanas viriam a acolher. Vinculada, indissociavelmente, ao design bidimensional dos núcleos urbanos, sendo, frequentemente, nos assentamentos mais regulares, a simples decorrência do vazio resultante da supressão de um dos quarteirões que deveriam compor a malha viária prevista no plano inicial (normalmente aquela quadra mais central), a plaza mayor se apresentaria como o "coração pulsante" das cidades fundadas pelos espanhóis, se confundindo, naturalmente, com as próprias cidades.

Parece consenso, entre os proeminentes pesquisadores da urbanística colonial, o fato da plaza mayor concentrar, nos séculos sob o domínio espanhol, as estruturas arquitetônicas que representariam as mais importantes funções religiosas, políticas, jurídicas, comerciais e de lazer da cidade colonial - apesar de que os assentamentos de fundação mais antiga apresentariam a tendência à divisão policêntrica das funções em diversos espaços públicos, como aconteceria nas cidades caribenhas de Santo Domingo e La Habana e na centroamericana Panamá, La Vieja (NICOLINI, 2001, p. 1088). Além disso, em grande parte dos assentamentos fundados no século XVI, a praça principal nasceria como o espaço apropriado para as tropas manobrarem, entrarem em formação e marcharem para os limites da urbe com o objetivo de protegerem a região dos invasores e revoltosos, especialmente os grupos nativos oponentes. Logo, a função militar poderia ser a mais importante ação geradora do grande vazio central das cidades, o que levaria a plaza mayor a ser também conhecida, em toda América hispânica, como plaza de armas (ROJAS MIX, 2006, p. 64).

No entanto, o elemento urbano conhecido como plaza mayor seria, grosso modo, proveniente da Metrópole. De origem medieval, frequentemente conformaria a principal praça da cidade, da mesma forma que aconteceria, após a conquista, nas Índias ocidentais. Mas, as plazas mayores espanholas abertas na Idade Média guardariam muito poucas relações, em termos de estrutura e paisagem, com aquelas que viriam a ser constituídas, e posteriormente consagradas, como uma das mais fascinantes criações da arquitetura e da urbanística na Península Ibérica, nos século XVI ao XIX.

Ao contrário das plazas de armas americanas, que figurariam imediatamente nos primeiros registros das trazas que permeariam a constituição ex novo das cidades virreinales, as mais significativas plazas espanholas seriam rasgadas no âmago de núcleos urbanos absolutamente consolidados - tanto as praças construídas na Idade Média, como aquelas de

(c) Urbana: Rev. Eletrônica Cent. Interdiscip. Estud. Cid. Campinas, SP V.10, n.1 [18] p.54-103 jan./mai. 2018 


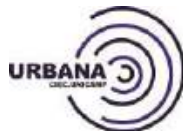

DOI: $10.20396 /$ urbana.v10i1.8651022

características arquitetônicas especiais levantadas a partir da Renascença. Mas, esta não seria a única diferença significativa entre as praças europeias e aquelas hispano-americanas. Para além da simplicidade quase vernácula de muitos organismos medievais formados por casas sustentadas por galerias abertas, as edificadas a partir da época de Felipe II na Espanha trariam como atributo essencial a uniformidade e a monumentalidade, aproximando-as, assim, das places royales francesas.

Mas, as analogias entre as duas tipologias urbanas não resistiriam além do fato de ambas estarem constituídas, formalmente, por uma conjunção de edifícios de fachadas idênticas e contínuas, frontarias que desenhariam uma estrutura interna de alto teor cenográfico, fundada na suposta presença de um único e amplo palácio que envolveria todos os lados das praças - ou, na pior das hipóteses, constituídas por imensas residências palacianas de arquitetura uniforme que conformariam as testadas ininterruptas dos quarteirões voltados para os largos.

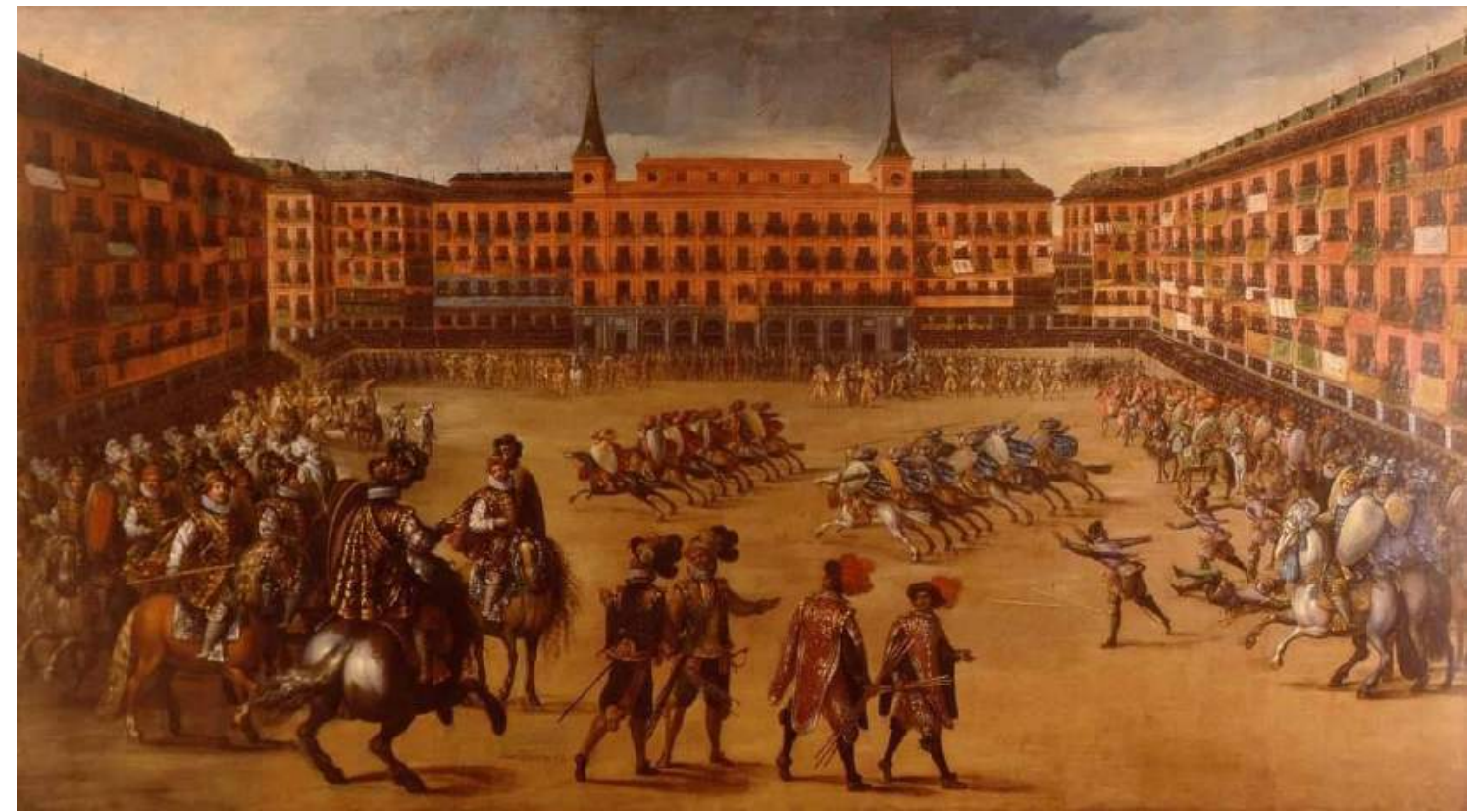

Figura 8 - Fiesta en la Plaza Mayor de Madrid. Pintura executada em 1623 pelo artista flamenco Juan de la Corte (1585-1662). Destaque para a Casa de la Panadería - ao fundo. Fonte: https://commons.wikimedia.org/wiki/File:Corte-plaza_mayor.jpg Acessado em 15 de novembro de 2017. 


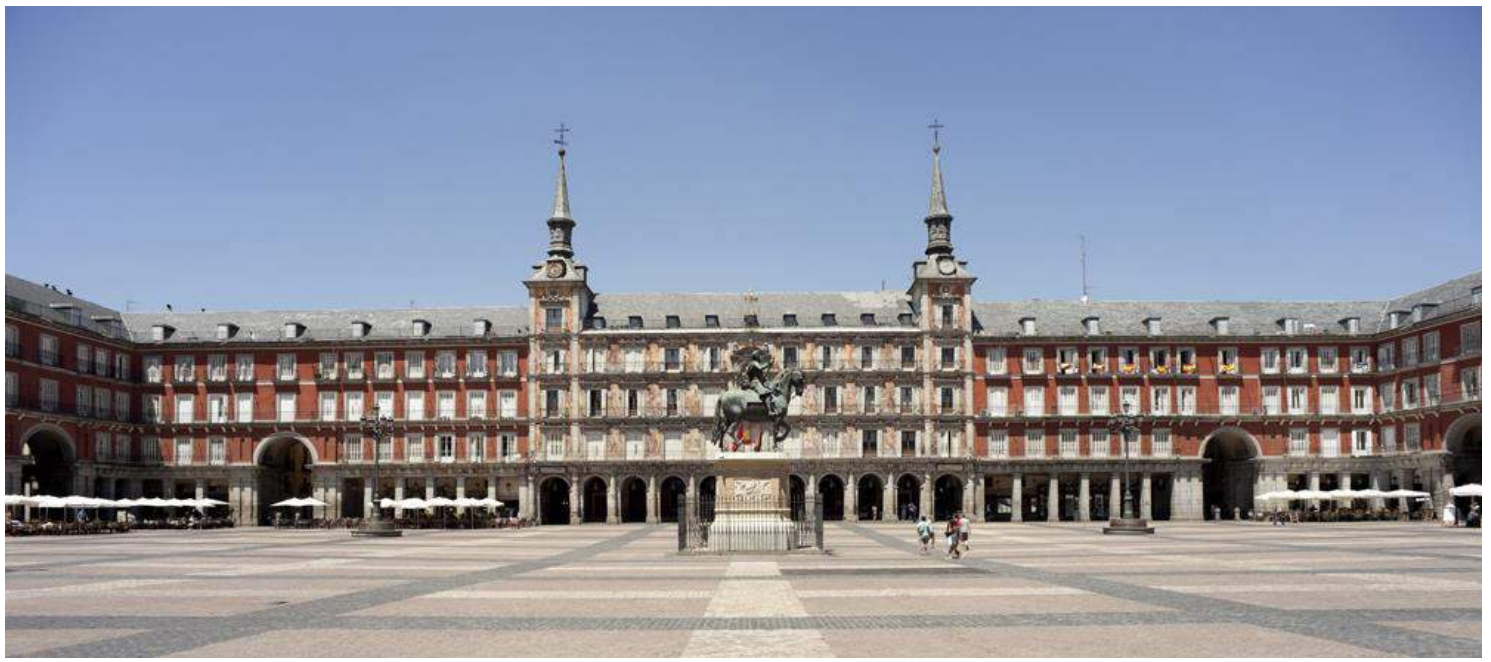

Figura 9 - Plaza Mayor de Madrid.

Fonte: https://commons.wikimedia.org/wiki/File:Corte-plaza_mayor.jpg Acessado em 15 de novembro de 2017. Fotografia de PMRMaeyaert.

As praças espanholas aspirariam a objetivos bastante diferenciados se confrontadas àquelas de ascendência francesa. As places royales da época dos monarcas Henrique IV, Luis XIII, Luis XIV e Luis XV, funcionariam como um eloquente teatro barroco no qual o rei deveria estrelar. Como o grande protagonista, dominaria o ambiente através de sua imagem representada pela faustosa estátua disposta no local mais proeminente do espaço - o ponto médio do "palco", envolvido pelo cenário formado pela sequência de fachadas "epidérmicas" contíguas de alto teor classicista. Numa outra direção, longe de ser um monumental ornato urbano levantado em honra e glória do rei, as plazas mayores espanholas teriam sua concepção vinculada a oferecer à população local um ostentoso e teatral ambiente desenhado para reunir um grande número de súditos e fiéis: seja para passeios diários, seja para acolher as mais diversas festas e espetáculos coletivos, ou mesmo para abrigar as populares corridas de toros - situações em que os tradicionais balcões lançados nas fachadas em todo o perímetro da praça serviriam como camarotes para a nobreza se deleitar com os espetáculos, enquanto a plebe ficaria disposta em efêmeras arquibancadas de madeira que circulariam a praça -, as uniformes plazas mayores estariam sempre desocupadas em seu núcleo central para viabilizar o adequado funcionamento dos inúmeros eventos populares. Ou seja, mesmo sem a presença marcante de estátuas equestres, obeliscos, fontes, cruzeiros, mesmo inexistindo símbolos do poder oficial ou religioso em seu cerne, as praças espanholas estariam, inevitavelmente, conectadas à persuasiva e retórica teatralidade barroca, sendo a mais importante "arena" desenhada para o convívio público dos cidadãos (Figuras 8 e 9).

Entretanto, esta importante tipologia arquitetônica e urbanística espanhola, fruto de

(c) Urbana: Rev. Eletrônica Cent. Interdiscip. Estud. Cid. Campinas, SP $\quad$ v.10, n.1 [18] p.54-103 jan./mai. 2018 
portentosos investimentos do governo imperial voltados à concepção de monumentais e sedutores artefatos persuasivos - artifício típico da cultura de massa do Barroco -, não encontraria ressonância nas plazas mayores americanas. Por um lado, o caráter essencial das imensas praças coloniais já estaria estabelecido e consolidado muito antes da construção da primeira praça uniforme na metrópole (a de Valladolid, em 1571), o que descartaria qualquer possibilidade de se vislumbrar influências peninsulares, renascentistas ou barrocas, na idealização e ordenação inicial das plazas de armas. Por outro lado, sua estrutura urbanística teria pouquíssimas relações, em termos de forma e função, com as praças espanholas - tanto com os ancestrais largos de origem medieval, quanto com as praças regulares humanistas ou iluministas erguidas pela realeza para o deleite de seus súditos. Pelo contrário, enquanto tipo, função e enquanto relação com o urbano, a plaza mayor hispano-americana seria uma criação absolutamente original, sem precedentes na cidade europeia.

$\mathrm{Na}$ verdade, a fusão de todos os mais importantes organismos públicos, oficiais e religiosos, em um único ambiente (LUCENA GIRALDO, 2006, p. 69) estaria em total desacordo com o que aconteceria, posteriormente, nas cenográficas criações barrocas das plazas mayores peninsulares e, igualmente, nas places royales francesas. Na Praça de Madrid, por exemplo, o edifício mais proeminente, localizado no ponto médio de um de seus lados maiores, ostentando duas torres que se destacariam na regularidade do ambiente, seria a Casa de la Panadería; o monumento que disputaria com a "padaria" o interesse dos passantes seria a Carnicería, ou seja, o "açougue" - diametralmente oposto do que aconteceria nas cidades coloniais, cujas plazas mayores acolheriam os grandes palácios administrativos, bem como o palácio arquiepiscopal e a catedral (ou a igreja maior, se a cidade não fosse sede de um bispado).

Assim, a plaza mayor seria o elemento urbano por onde começaria a ser assentada a cidade; desde o primeiro instante, o núcleo já contaria com a igreja paroquial, ou a catedral, e o palácio de governo municipal dispostos na praça (Figuras 10 e 11). Além disso, durante o ato de fundação, seria levantada a picota ou o rollo: segundo Fagiolo (1975, p. 36), uma coluna sobreposta por uma cruz que seria o símbolo máximo da cidade e da justiça, equivalente ao papel que assumiria o pelourinho no mundo lusitano. Também seriam erguidas, no vazio central da praça, a forca para a punição capital dos condenados e a fonte, que além de abastecer o povoado, assumiria um sentido simbólico de "regeneração" para o núcleo urbano, "fonte da vida", em oposição à ideia da penalização dos infratores torturados no rollo. 

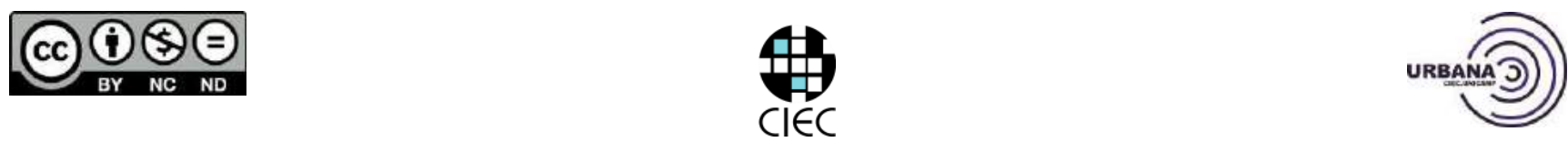

DOI: $10.20396 /$ urbana.v10i1.8651022

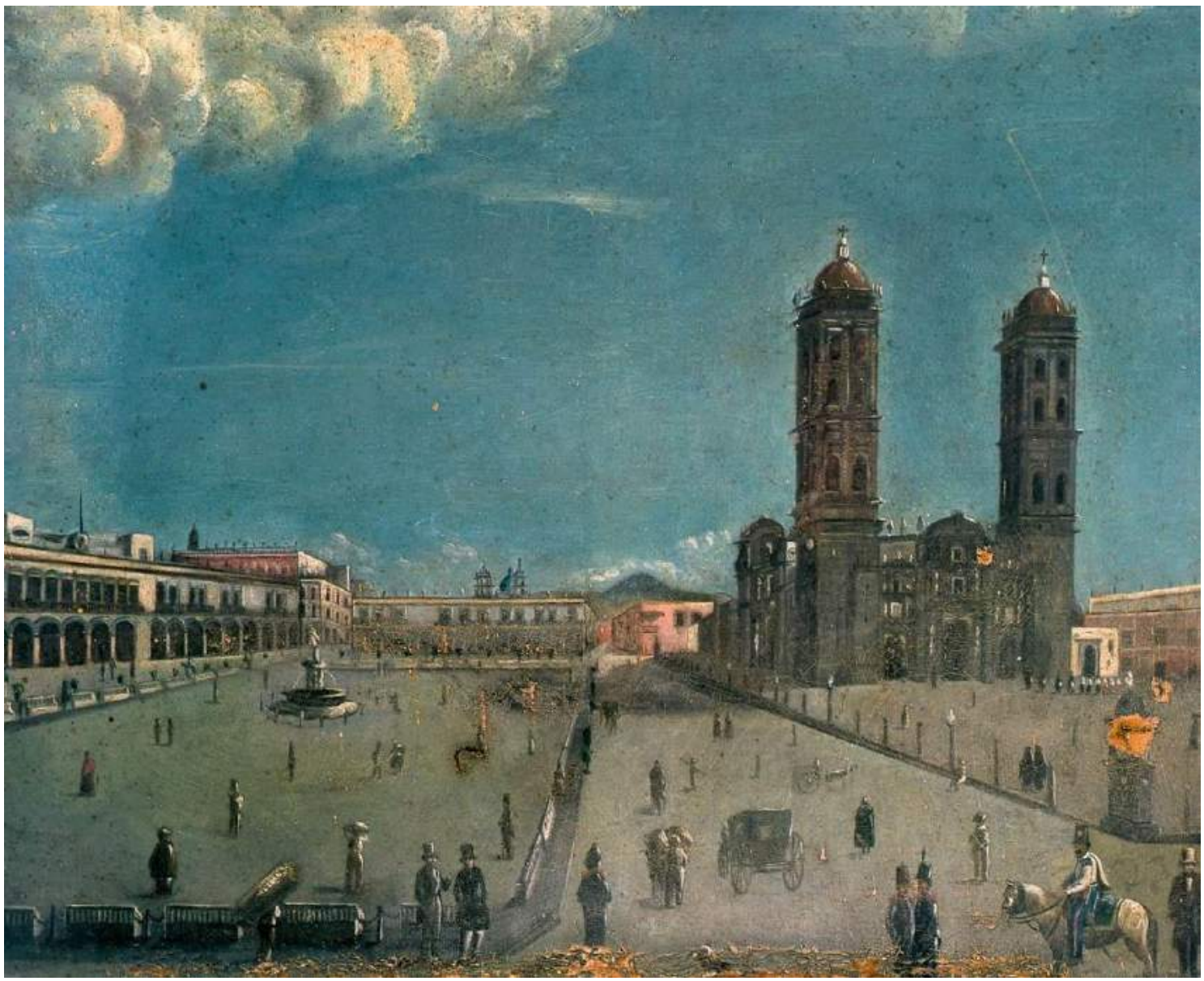

Figura 10 - Plaza principal de Puebla. Óleo sobre tela, pintado por José María Fernández, em 1835, mostrando a Catedral de Puebla com sua implantação de costados para El Zócalo. O edifício foi projetado por Francisco Becerra em 1572.

Fonte: Allende Carrera (2006, p. 151). 

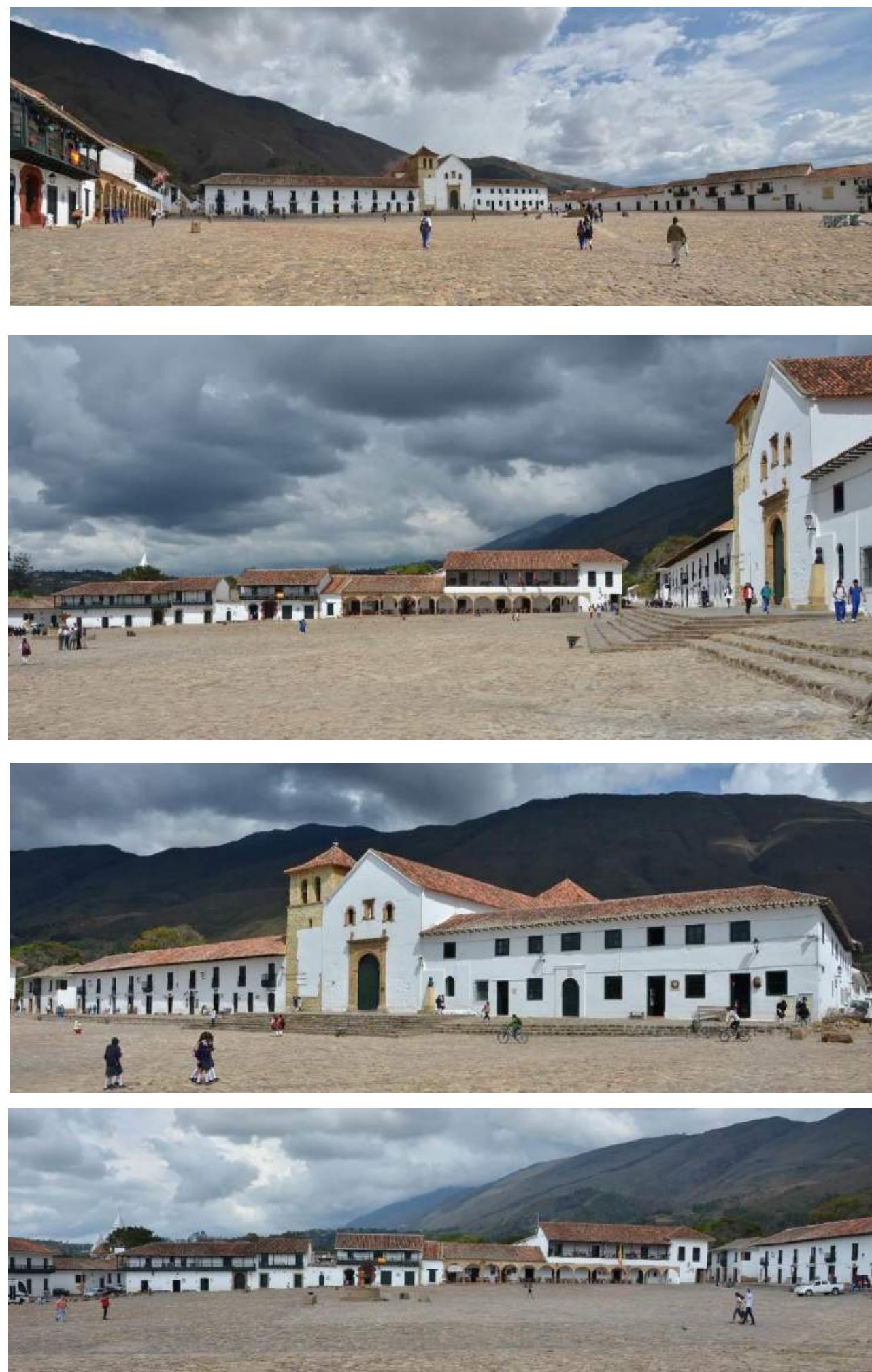

Figura 11 - Panoramas retirados da enorme Plaza Mayor da Villa de Leyva (Colômbia), com destaque para a Igreja Paroquial e para o casario componente.

Fonte: Fotografias do autor, 2013.

(c) Urbana: Rev. Eletrônica Cent. Interdiscip. Estud. Cid. Campinas, SP v.10, n.1 [18] p.54-103 jan./mai. 2018 
Com o tempo, outros importantes organismos municipais, assim como as sedes dos governos regionais das capitais, o palácio do bispo, o cárcere e outras construções ligadas à administração colonial e à justiça, em conjunção com os casarões dos fundadores e dos proeminentes conquistadores, envolveriam a plaza mayor, que ganharia, em um ou mais de seus lados, portales para o abrigo do sol, do frio e da chuva. Imediatamente, o mercado indígena, conhecido em toda América hispânica como tianguez, seria organizado no amplo vazio da plaza mayor, vazio que, algumas vezes, alcançaria dimensões verdadeiramente colossais. O amplo espaço da praça também receberia os mais importantes espetáculos públicos e as festas religiosas; para isso, a maioria das plazas de armas não receberia pavimentação durante os primeiros séculos da conquista, para viabilizar as ações ligadas ao grande evento da tourada.

Para Gutiérrez (1997, p. 92), o ambiente monumental da plaza de armas, não obstante ser supostamente concebido para a população branca, resgataria, na intensa apropriação que sofreria por parte da gente nativa, algo do valor que os espaços abertos donotariam para os grupos autóctones nos antigos núcleos pré-colombianos - seja na invasão diária ou semanal da praça pelo tianguez, ou mesmo nas festas religiosas e políticas celebradas no grande vazio, eventos que os ameríndios eram obrigados a participar.

Neste sentido, além do impulso centrífugo de desenvolvimento que o núcleo sofreria desde a constituição inicial da plaza mayor, a cidade colonial também absorveria uma poderosa força centrípeta, já que todo organismo urbano estaria direcionado à praça. Enquanto as estruturas representativas dos poderes imperiais, religiosos, jurídicos, bem como as atividades de comércio e lazer, em cidades como Paris, Roma, Lisboa, Praga, Madrid, estariam espalhadas por todo o assentamento urbano, nas mais representativas cidades coloniais estas estruturas se concentrariam, quase que invariavelmente, na praça, oferecendo às urbes hispano-americanas um teor de centralidade com um calibre que dificilmente teria equivalência no Velho Continente.

Mo entanto, durante o século XVI, a paisagem retirada das plazas mayores ainda contaria com um caráter precário e algo rarefeito, só ganhando a expressão que viria consagrá-las no período barroco - apesar de que algumas praças continuariam inacabadas e improvisadas até o século XVIII.

\section{Estrutura e paisagem nas cidades hispano-americanas no século XVI: a arquitetura monumental distribuída pelo núcleo urbano}

Fora de seu contexto imediato, os outros espaços urbanos relevantes e as estruturas

(c) Urbana: Rev. Eletrônica Cent. Interdiscip. Estud. Cid. Campinas, SP $\quad$ v.10, n.1 [18] p.54-103 jan./mai. 2018 
arquitetônicas significativas que ocupariam a cidade quinhentista estariam dispostos nos quarteirões circunvizinhos, não retirando, todavia, a hegemonia da plaza de armas na constituição hierárquica da paisagem colonial. A maioria dos organismos que viriam a se destacar, para além dos domínios da praça, seriam de filiação religiosa, especialmente os imensos conjuntos formados pelos conventos, colégios, e pelos mosteiros. Redutos da ordem franciscana, ou dos dominicanos, jesuítas, agostinianos, mercedários, estes complexos arquitetônicos estariam espalhados por todo o núcleo urbano, deixando grandes áreas sob sua decisiva influência: frequentemente atribuindo ao bairro, ou pelo menos ao setor urbano no qual estariam inseridos, sua denominação e devoção; até mesmo a alcunha de uma cidade poderia derivar destas ordens religiosas. Também poderosos seriam os monastérios vinculados às ordens femininas - clarissas, carmelitas, dominicanas - construídos, nas cidades hispanoamericanas, nas imediações da grande praça, assim como os hospitais e os seminários.

As estruturas conventuais poderiam atingir uma escala arquitetônica verdadeiramente gigantesca, ocupando mais de uma quadra da cidade, acolhendo a igreja principal em local de destaque, os templos adjacentes ligados à ordem, as várias capelas, claustros, refeitórios, dependências, hortas. Seria o caso do Convento de San Francisco de Quito, construído a partir de 1553 sobre as ruínas do palácio do imperador inca Huayna Capac (ESCUDERO ALBORNOZ, 2006 , p. 80). Com seus sete claustros, sua imponente igreja maior, dois templos menores, inúmeras capelas e ainda um colégio, o convento ocuparia, na sede da Audiencia y Cancillaría Real de Quito, uma área próxima à de quatro quarteirões. Igualmente colossal seria o antigo convento dedicado à mesma ordem na cidade de Lima, complexo arquitetônico que contaria com seis claustros, assentado em mais de duas das grandes quadras da antiga Ciudad de los Reyes.

Independentemente de sua dimensão, seria muito raro qualquer um dos complexos eclesiásticos não despontar precedido por um adro rasgado na traza da cidade colonial. Muitas vezes, este espaço se comportaria como uma praça pública com uma fonte aberta à frente da igreja principal da ordem, edifício que estaria conectado fisicamente ao convento ou ao monastério adjacente. Contudo, nas cidades regulares, os largos das igrejas e dos conventos frequentemente contariam com pequenas dimensões, podendo apresentar-se como um reduzido "recorte" efetuado nas testadas das quadras: por exemplo, um adro desenhado em uma esquina importante da cidade, situação esteticamente aprazível - repetida centenas de vezes - em que uma das laterais da igreja estaria alinhada com a via, mas não preencheria toda a extensão do segmento da rua, deixando no próximo cruzamento, diante de sua fachada, um espaço vazio limitado pela largura do frontispício (Figuras 12 e 13). Mas, esta subserviência dos limitados espaços urbanos sacralizados frente à monumentalidade da plaza 
de armas poderia ser, eventualmente, quebrada, quando o ambiente do adro antecipasse uma estrutura religiosa de grande relevância para a ordenação da cidade (Figuras 14 e 15).

Ainda nas cidades virreinales, igrejas paroquiais e capelas de irmandades, com seus respectivos adros, bem como edifícios ligados à administração pública, ao controle alfandegário, tribunais de justiça e de inquisição, construções levantadas para o comércio e para a produção, poderiam se destacar no cenário urbano; mas nada que no século XVI pudesse se comparar à força alcançada na paisagem urbana pelos conjuntos monásticos e, especialmente, pelo complexo das plazas mayores.

(c) Urbana: Rev. Eletrônica Cent. Interdiscip. Estud. Cid. Campinas, SP v.10, n.1 [18] p.54-103 jan./mai. 2018 
DOI: $10.20396 /$ urbana.v10i1.8651022
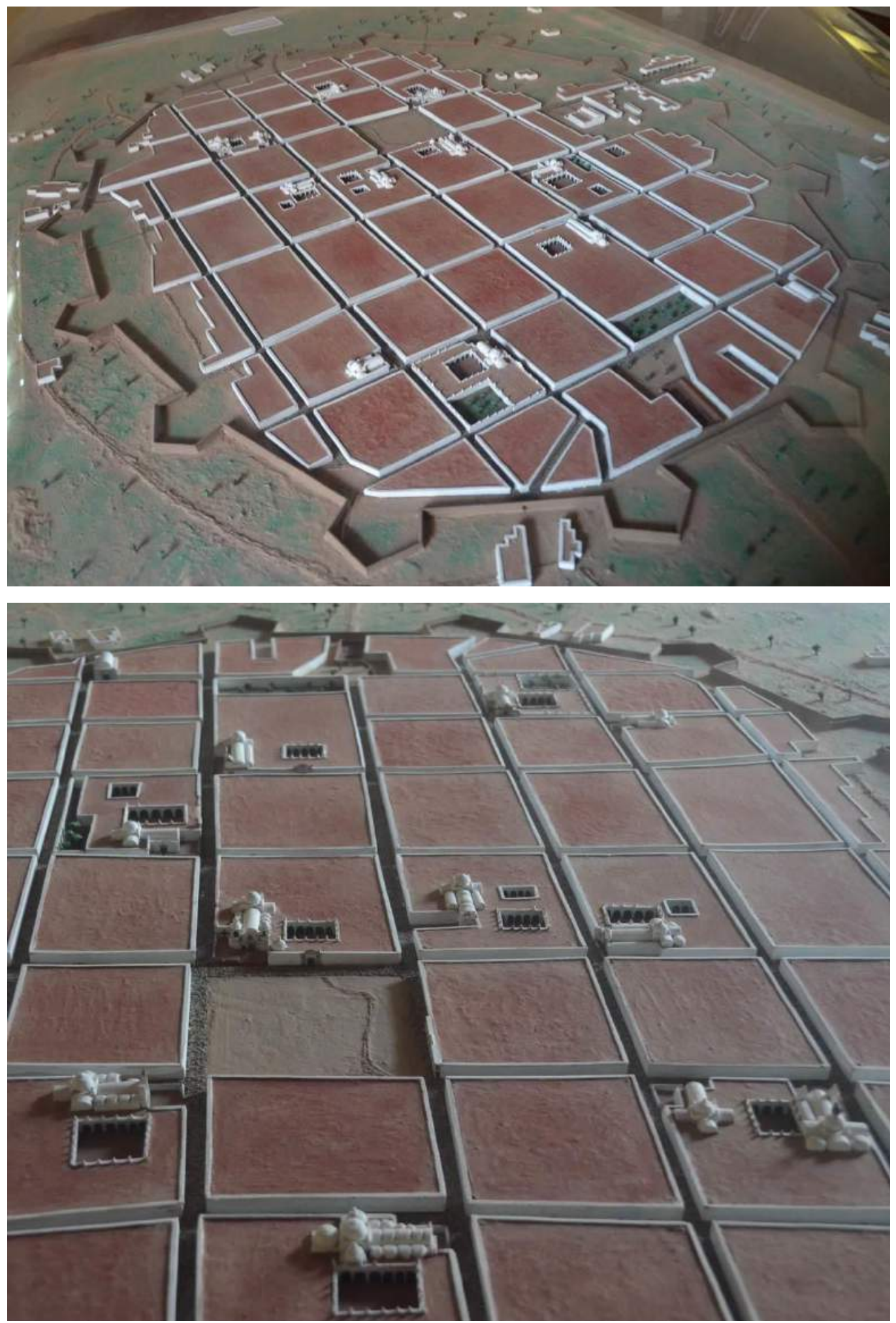

Figura 12 - Maquete da cidade de Trujillo, no Peru (fundada em 1535), retratando-a no século XVIII. Percebe-se, para além da grande estrutura vazia da Plaza Mayor que abriga a Catedral, os pequenos recortes dos quarteirões feitos para acolher as praças que se abriam para igrejas, conventos e outras estruturas arquitetônicas religiosas.

Fonte: Fotografias do autor, 2015. A maquete se encontra no Museu Casa Urquiaga.

(c) Urbana: Rev. Eletrônica Cent. Interdiscip. Estud. Cid. Campinas, SP v.10, n.1 [18] p.54-103 jan./mai. 2018 


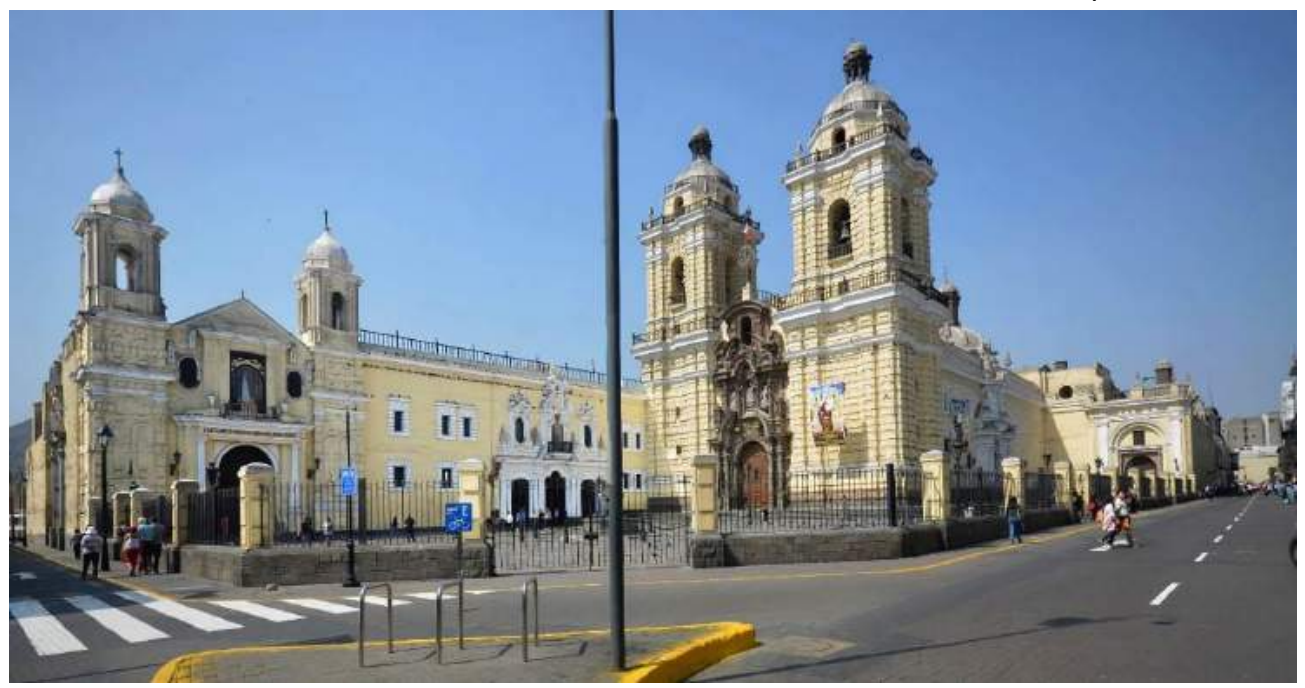

Figura 13 - Recorte em quarteirão do centro histórico de Lima (Peru) feito para acolher a Igreja do Convento de San Francisco - fundado na segunda metade do século XVI.

Fonte: Fotografia do autor, 2015.

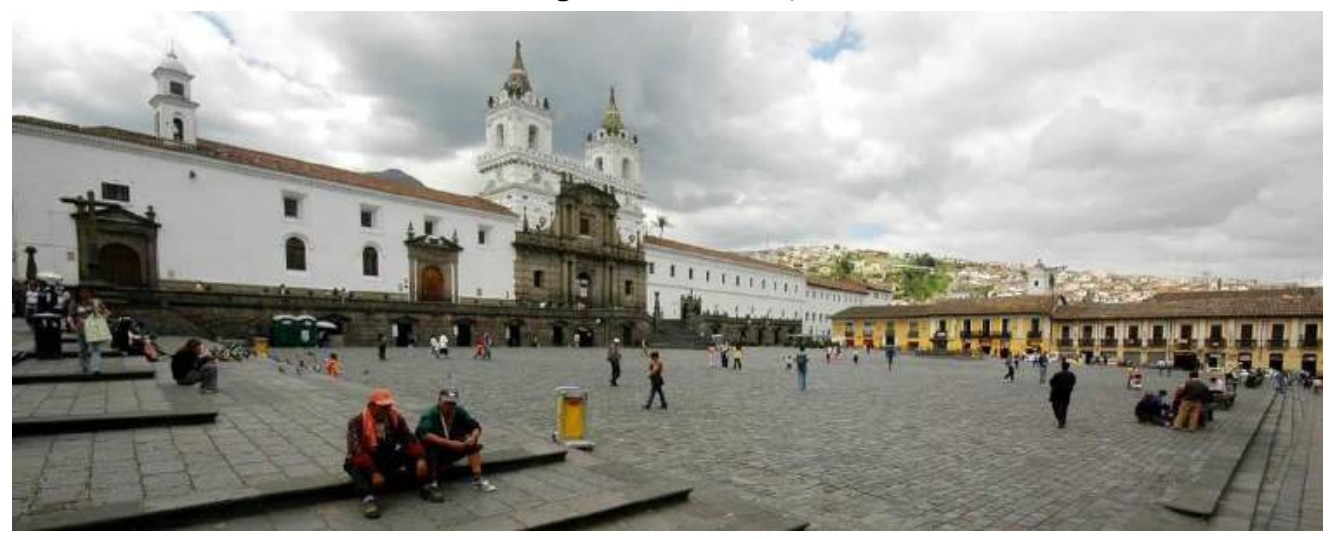

Figura 14 - Grande praça que acolhe a Igreja e o Convento de San Francisco em Quito (Equador) - fundado por volta de 1537. A praça era o antigo tianguez (mercado indígena). Fonte: Fotografia do autor, 2007.

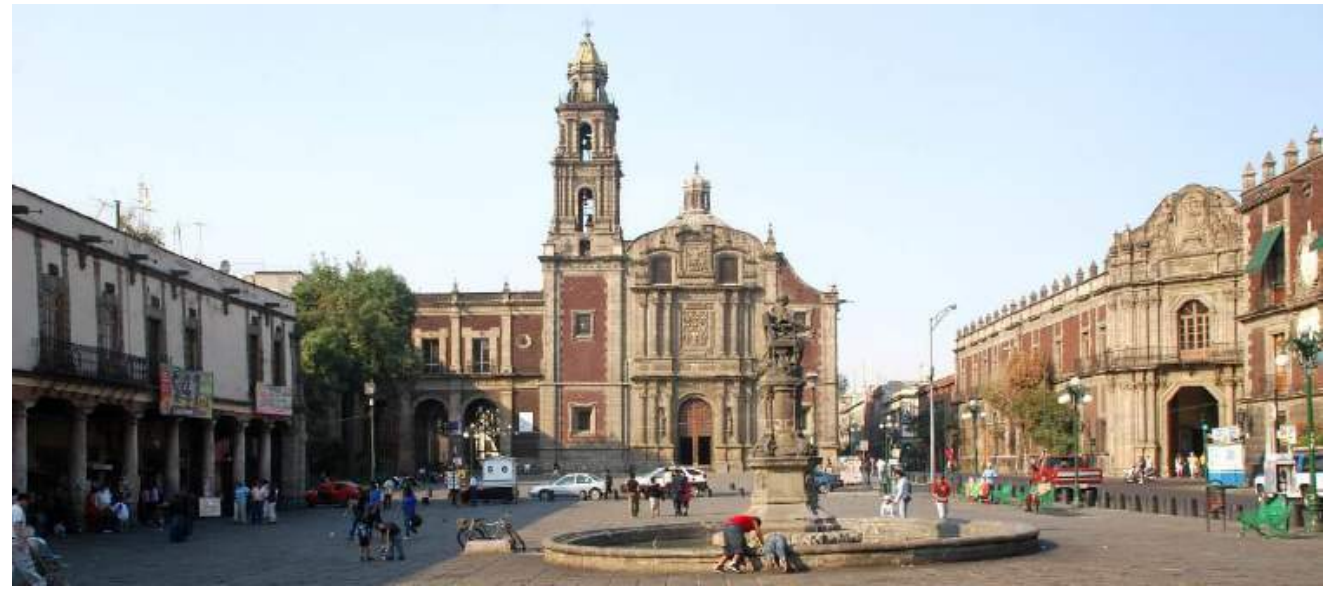

Figura 15 - Praça que acolhe a Igreja e o Convento de Santo Domingo na Cidade do México fundado na primeira metade do século XVI.

Fonte: Fotografia do autor, 2009. 


\section{O adensamento das cidades hispano-americanas no século XVIII}

Nas centúrias subsequentes à fundação e à implantação das trazas regulares das mais importantes cidades hispano-americanas, os rígidos planos abstratos, que tomariam forma no século XVI com o assentamento do sistema viário, teriam sua imagem preexistente vitimada pelo crescimento interno das cidades - mesmo admitindo a manutenção integral da estrutura viária original. O primeiro aspecto essencial deste processo de transformação se daria através da gradativa subdivisão dos desmedidos solares destinados aos conquistadores e fundadores em diversos lotes de menores dimensões:

A rápida densificação urbana, efeito do processo geral de urbanização, trouxe como consequência a subdivisão dos grandes lotes do século XVI, provocando o desaparecimento da casa-horta privada dos primeiros colonizadores espanhóis e o aparecimento de lotes de pouca frente e muita profundidade nas novas zonas de expansão urbana e nos novos traçados de cidades, especialmente durante a segunda metade do século XVIII. (MATTOS-CARDENAS, 1984, p. 60 - tradução nossa)

Como diria Leonardo Mattos-Cardenas, os imensos solares dos núcleos urbanos virreinales não resistiriam ao desenvolvimento e à prosperidade econômica das cidades, sendo invariavelmente parcelados, provocando a substituição dos quintais e hortas dos casarões antigos, por massa edificada - por arquitetura. Quanto mais próximos em relação à plaza mayor, maiores subdivisões ganhariam, determinando o aparecimento de infindáveis lotes de pequenas dimensões (Figura 16) - prática que, segundo afirmaria o pesquisador peruano, teria influenciado diretamente os planos de expansão e os projetos de cidades novas instituídos a partir da segunda metade do século XVIII.

O fato dos preexistentes solares privados passarem a contar com uma fração mínima de seu tamanho original decretaria que os lotes, parcelados e reordenados longitudinalmente em direção ao centro dos quarteirões, começariam a acomodar frentes de largura menor testadas reduzidas para o contexto da urbanização hispano-americana (mas ainda muito vastas em comparação às luso-brasileiras), distribuídas ritmadamente por toda extensão das ruas. Deste modo, tornar-se-ia impositivo o aproveitamento máximo das áreas destinadas à construção, dando continuidade à tradição peninsular de edificar casas com pátios que deveriam ocupar todo terreno, não sendo admitidos recuos frontais ou laterais (Figura 17).

Além disso, quanto mais valorizados fossem os novos lotes, quando mais centrais as casas privadas estivessem, haveria uma maior tendência à sua verticalização, o que na 
América hispânica significaria a existência de imponentes casarões - construções que teriam, no entanto, um número máximo de dois pavimentos, mesmo nos setores mais valorizados da urbe. O gabarito superior das construções, bem como a constante regularidade das alturas dos sobrados; a multiplicação das edificações e a consequente ausência daqueles vazios que despontariam nas testadas dos antigos solares; tudo isso somado ao fato das edificações civis se apresentarem contíguas, agregadas umas às outras e rigidamente alinhadas com as vias, atribuiriam, aos panoramas retirados de dentro da grelha ortogonal, um forte impulso perspectivo. A interminável sequência das fachadas dos sobrados residenciais ou de uso misto - comércio no térreo e residência no piso superior -, ordenada de forma retilínea, flanqueando as duas faces das vias mais importantes, produziria "paredes" de edificações trabalhadas com ricas, ritmadas e variadas modenaturas, marcações que colaborariam para a aceleração daquela fuga em profundidade que buscaria, obsessivamente, o plano infinito - não obstante as interrupções dos cruzamentos regulares.

No entanto, dever-se-ia reiterar que esta fuga perspectiva, que poderosamente se dissiparia no horizonte infinito, voltando-se para as quatro direções que as artérias das cidades regulares invariavelmente apontariam, só seria fundamentalmente manifesta quando a estrutura inicial de parcelamento de solares dos assentamentos virreinales fosse fatalmente implodida em prol do adensamento das cidades.

E é claro que algumas vias mais bem localizadas passariam pelo processo de saturação da massa edificada e de monumentalização da sua arquitetura civil de maneira mais intensa e imediata que outras áreas menos favorecidas. Logo, aconteceria, espontaneamente, um processo de hierarquização visual de algumas ruas, mesmo para os assentamentos que seguiriam o padrão da traza ortogonal mais regular, nos quais as vias, centrais ou periféricas, possuiriam, insistentemente, a mesma largura. Especialmente privilegiadas seriam aquelas que partiriam da plaza de armas, ou que alcançariam suas proximidades, avenidas que ganhariam um caráter grandiloquente e uma animação até então inéditos, direcionando o cenário urbano para uma constituição paisagística definitivamente dramática (Figura 18). 


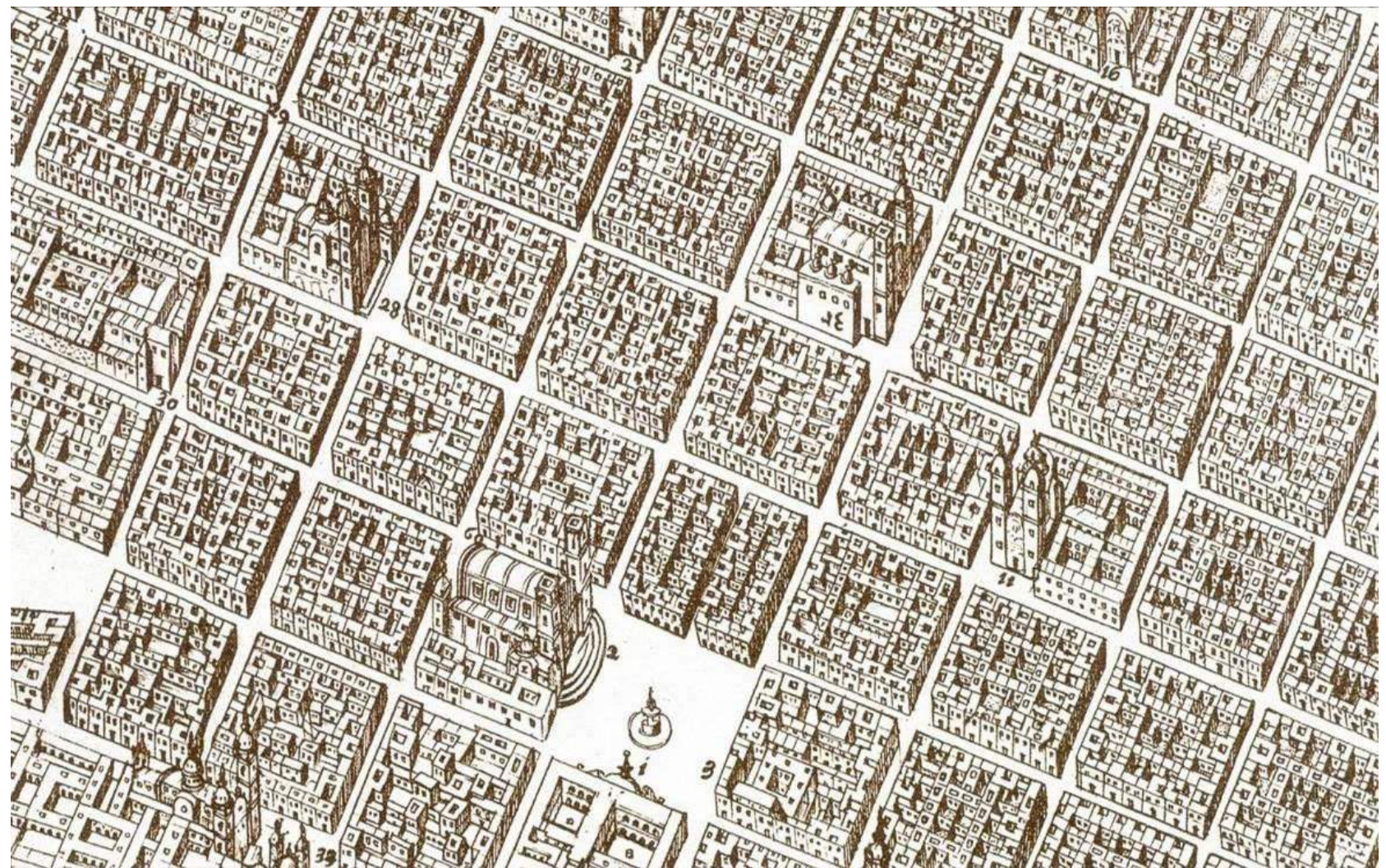

Figura 16 - Detalhe do Plano de Lima, confeccionado em 1744. Os quatro solares originalmente distribuídos em cada quadra já haviam sido substituídos por lotes muito menores, definindo uma ocupação de $100 \%$ das testadas dos quarteirões Fonte: Benevolo (2006, v. 3, p. 113). 

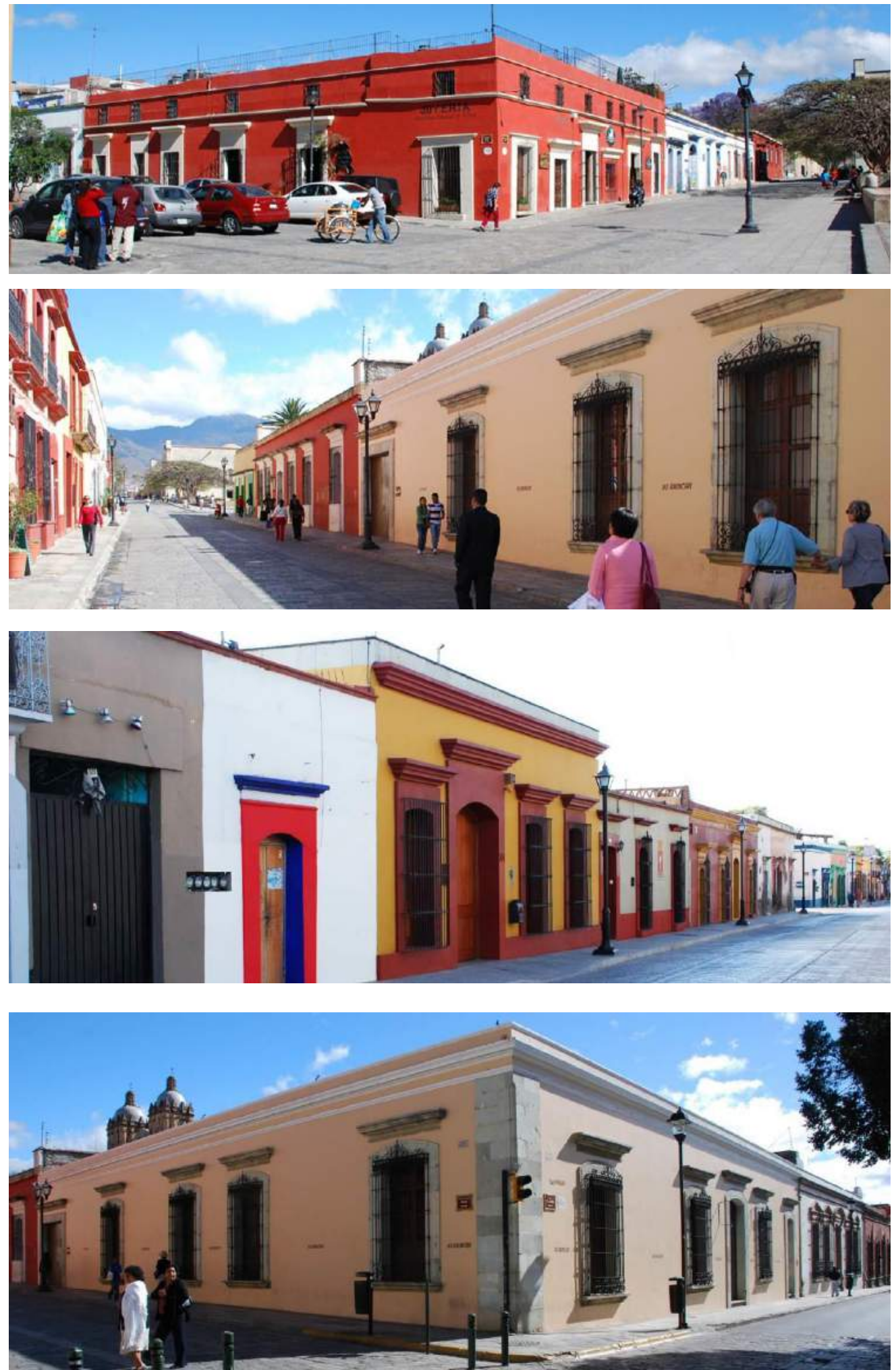

Figura 17 - Vias e quarteirões de Oaxaca, com destaque para os rasantes edifícios residenciais alinhados, a uma certa distância da praça principal. Fonte: Fotografias do autor, 2009.

(c) Urbana: Rev. Eletrônica Cent. Interdiscip. Estud. Cid. Campinas, SP v.10, n.1 [18] p.54-103 jan./mai. 2018 

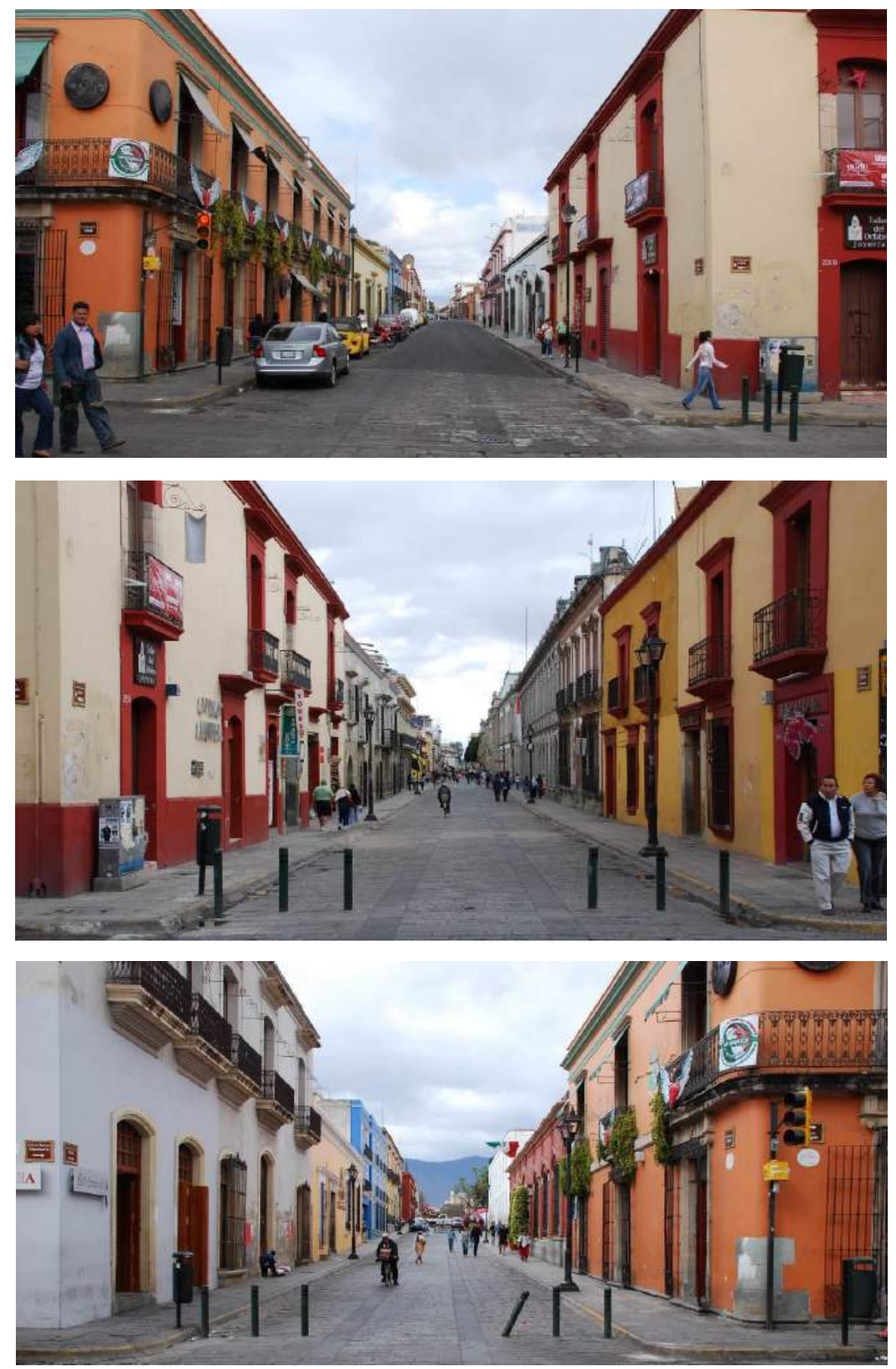

Figura 18 - Ocupação mais densa, com casarões alinhados e contíguos, formando encaminhamentos perspectivos nas adjacências da Plaza Mayor de Oaxaca. Fonte: Fotografias do autor, 2009. 


\section{Contra a quadrícula: o processo de dramatização da paisagem urbana hispano-americana no século XVIII}

Mesmo com o adensamento das cidades, na América espanhola a racional e burocrática cidade regular atuaria, paradoxalmente, contra o processo de dramatização do espaço urbano - artifício comum nos faustosos empreendimentos barrocos nos séculos XVII e XVIII que afetariam diversos núcleos urbanos europeus. A quadrícula apresentaria uma tendência natural à monotonia que, obviamente, não combinaria com o jogo persuasivo e dramático apregoado pelas imagens frenéticas lançadas no espaço urbano, situação característica da poética urbana seiscentista e setecentista.

Assim, muitas das iniciativas praticadas no século XVIII, voltadas ao universo da urbanística - assim como grande parte das ações ligadas aos domínios da arquitetura e que tocariam a paisagem urbana -, quando versadas na aplicação para o ambiente urbano do espírito teatral do Barroco, operariam em forte confronto e oposição ao modelo de cidade em damero consolidado no século XVI; seriam iniciativas que agiriam, parodoxalmente, contra a quadrícula.

Haveria uma tendência, expressa nos assentamentos que receberiam uma configuração viária mais aprisionada, cujos planos estariam diretamente atrelados ao esquema mais rígido de orientação do traçado, a se prestarem mais timidamente às renovações cenográficas da paisagem urbana. Ao se comparar as cidades configuradas como um perfeito e imaculado tabuleiro de xadrez, com os assentamentos virreinales delineados a partir de diagramas viários menos engessados, seria possível constatar que os últimos aceitariam melhor as intervenções que atuariam contra a quadrícula; consequentemente, estariam mais bem preparados para se transformarem em cenográficas cidades cujos panoramas seriam regidos pela poética barroca.

Para a cidade em forma de grelha, pequenas concessões à severidade da malha ortogonal, cujas ruas, praças e quarteirões contariam, usualmente, com as mesmas dimensões, poderiam ser suficientes para suscitar expedientes que auxiliassem a aparição de acontecimentos dramáticos pontuados na paisagem urbana, eventos que atuariam em prol da constituição de um cenário de alto teor dramático. Uma rua contígua à plaza mayor, aberta com uma largura ligeiramente superior às das outras vias, poderia transformar-se em um evento de enorme destaque no seio da cidade: com o tempo e com a nova distribuição fundiária dos solares, a antiga via poderia acolher, prontamente, uma sequência ininterrupta de imponentes casarões e de palácios institucionais aos dois lados de cada segmento de rua, tornando-se a poderosa e monumental avenida senhorial do núcleo urbano, assim como, seu

(c) Urbana: Rev. Eletrônica Cent. Interdiscip. Estud. Cid. Campinas, SP v.10, n.1 [18] p.54-103 jan./mai. 2018 
mais importante eixo de circulação - processo que favoreceria a configuração hierárquica da cidade e que revelaria os objetivos da coroa espanhola de expressar, no ambiente urbano, a retórica e a persuasão barrocas.

Na mesma direção, os núcleos urbanos que possuiriam geneticamente um traçado mais flexível, mesmo seguindo a tradição viária da grelha, aceitariam mais naturalmente o aparecimento de frontarias e portadas de templos, conventos, palácios, que atravancariam as ruas originalmente diretas, gerando - na conclusão em profundidade do eixo - aquele desejado encerramento perspectivo característico da urbanística barroca.

No que se refere, especificamente, à arquitetura religiosa, já foi discutido que muitos complexos arquitetônicos alcançariam grandes dimensões ainda no século XVI, chegando a cobrir, no âmago das cidades, uma área equivalente a duas ou mais quadras do núcleo urbano regular, invadindo diversos segmentos das longas ruas, que até então figurariam diretas e contínuas. Em consequência, a grande extensão de terra utilizada para o assentamento de certas catedrais, assim como o imenso espaço destinado às cercas de determinados conventos e monastérios, acabariam, inevitavelmente, provocando singulares enquadramentos perspectivos que despontariam na finalização de algumas vias; eixos que, segundo o plano original, deveriam se estender ininterruptamente até os limites da mancha urbana edificada, mas que agora seriam detidos ao atingirem perpendicularmente os imensos conjuntos religiosos. Seriam situações de alto teor cenográfico em que o ponto de fuga ficaria emoldurado por uma trabalhada portada barroca, pela presença de altas torres e campanários, ou mesmo pelo aparecimento de um elaborado frontispício, efusivamente ornamentado.

Como exemplo, a configuração mais flexível do traçado urbano da antiga Valladolid de Michoacán (atual Morelia) possibilitaria a construção de múltiplos expedientes caros à urbanística barroca: a presença de um eixo dominante que cruza a cidade, com uma largura superior às outras ruas, e acolhendo muitos dos principais monumentos religiosos, institucionais e civis - a Calle Real (Figura 19); encaminhamentos perspectivos direcionados em profundidade a específicos points de vues, emoldurados por fachadas ou portadas de igrejas - a Catedral, a Igreja do Convento de San Agustín, a Igreja de San José, o Templo de las Rosas (Figura 20); a distribuição radial de vias e equipamentos que aconteceria no limite oriental da imponente Calle Real - o leque no qual passaria o aqueduto da cidade; a abertura de um passeio arborizado (adjacente ao aqueduto), retilíneo e perspectivo, direcionado a uma importante estrutura religiosa - a Calzada de Guadalupe (Figura 21).

Neste sentido, seria significativo o fato da arquitetura monumental, componente da

(c) Urbana: Rev. Eletrônica Cent. Interdiscip. Estud. Cid. Campinas, SP v.10, n.1 [18] p.54-103 jan./mai. 2018 
cidade de Morelia, prescindir de um forte caráter decorativo e expressivo, preferindo uma composição mais sóbria, apesar de absolutamente imponente, grandiosa. Provavelmente, a cidade hispano-americana que mais se apropriaria das soluções urbanísticas vinculadas às intervenções praticadas no Barroco não necessitaria de uma arquitetura de grande expressão cenográfica para provocar a virtual transformação de seu ambiente em prol da persuasiva exaltação do poder da coroa espanhola e da Igreja católica.
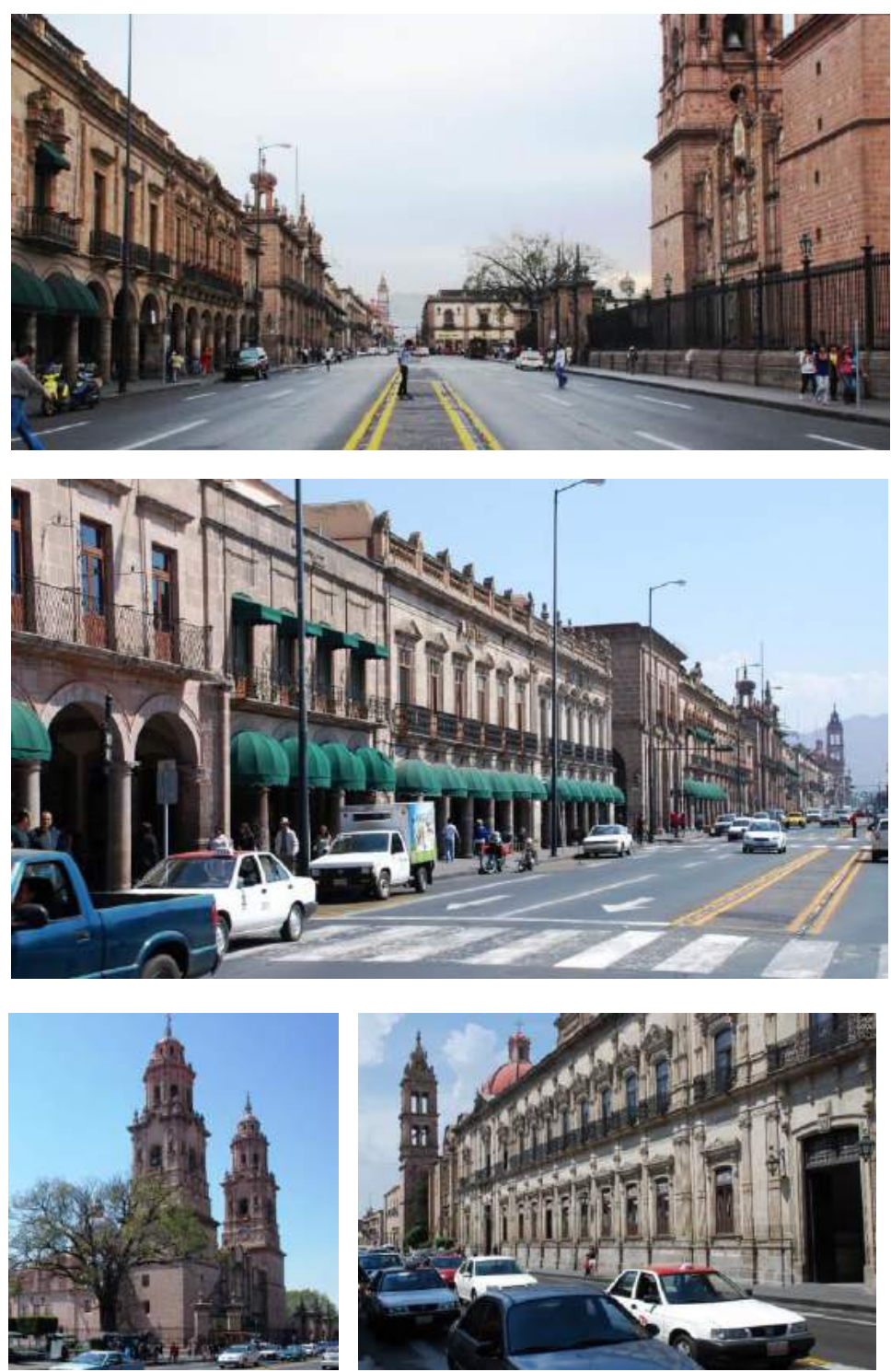

Figura 19 - Panoramas perspectivos da Calle Real da cidade de Morelia, México (fundada em 1541), com destaque para a Catedral e para a torre e a cúpula do Templo de las Monjas. Fonte: Fotografias do autor, 2009. 

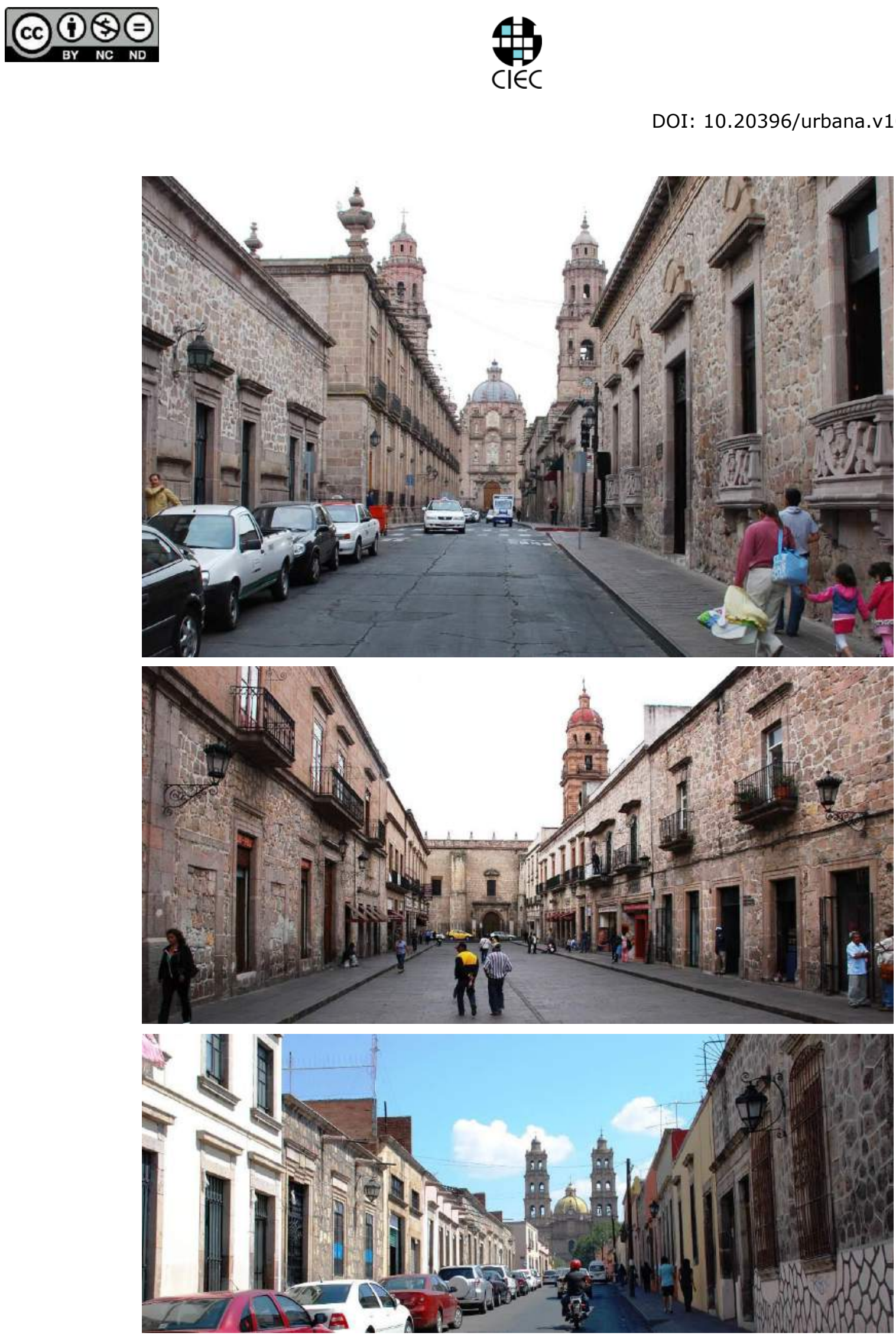

Figura 20 - Fugas perspectivas direcionadas a edifícios religiosos na cidade de Morelia: Catedral; fachada lateral da Igreja do antigo Convento de San Agustín; Igreja de San José. Fonte: Fotografias do autor, 2009. 


\section{$\underset{C \mathrm{P} \in \mathrm{C}}{\operatorname{M}}$}

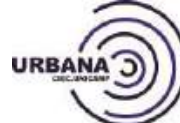

DOI: $10.20396 /$ urbana.v10i1.8651022

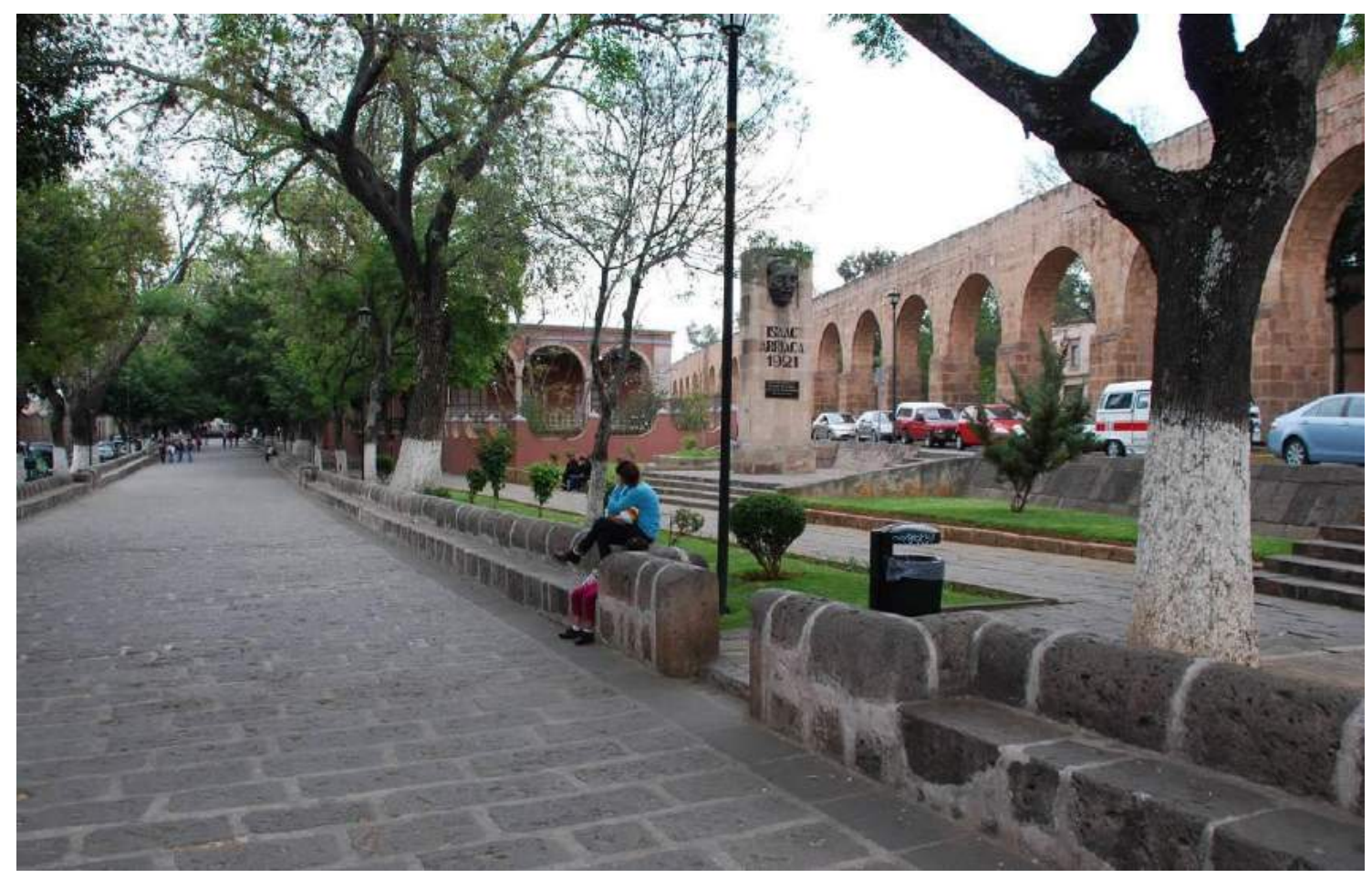

Figura 21 - Morelia. Ao final da Calle Real se Inicia a alameda que segue em direção ao Santuário de Guadalupe, com o aqueduto passando ao lado - conhecida como Calzada de Fray Antonio de San Miguel, ou Calzada de Guadalupe.

Fonte: Fotografia do autor, 2009.

\section{As plazas mayores e o "giro" das igrejas matrizes e das catedrais}

A grande maioria das cidades virreinales não abandonaria, no século XVIII, uma de suas características essenciais: os núcleos urbanos continuariam sendo profundamente centralizados, guardando, para as plazas mayores, o papel de protagonistas no espetáculo urbano - o principal evento citadino. Para isso, receberiam, invariavelmente, diversas intervenções em prol de sua monumentalização e de sua dramatização: construção ou ampliação das galerias abertas em arcadas (os portales), que muitas vezes preencheriam os alinhamentos frontais de dois ou três lados da praça, sempre excluindo a face na qual teria sido levantada a igreja matriz ou a catedral; substituição das primeiras fontes construídas na área central das colossais praças (concebidas, inicialmente, como simples equipamentos de fornecimento d'água) por monumentais chafarizes escultóricos - bem como substituição de outros marcos simbólicos assentados no ponto médio do vazio do espaço público por novas e movimentadas estruturas barrocas; construção de edifícios ligados aos poderes institucionais e jurídicos, ou reforma dos já existentes; adensamento dos solares originais destinados aos fundadores, eliminando os vácuos do alinhamento das faces dos quarteirões que compunham o perímetro da praça - contribuindo para produzir a típica sensação de clausura na cavidade interna do ambiente.

(c) Urbana: Rev. Eletrônica Cent. Interdiscip. Estud. Cid. Campinas, SP V.10, n.1 [18] p.54-103 jan./mai. 2018 
No entanto, as ações mais interessantes e eficientes de intervenção sobre a preexistência das plazas mayores em muitas das cidades virreinales se refeririam ao problema da implantação das igrejas matrizes - que com o tempo seriam usualmente promovidas a catedrais - nos imensos solares destinados à sua construção pelos conquistadores das desoladas regiões e pelos fundadores dos assentamentos coloniais. Segundo Alberto Nicolini:

Um exame cuidadoso da cartografia urbana hispano-americana disponível permite verificar que, durante o século XVI, a igreja matriz das novas cidades recém-fundadas teve uma forma peculiar de situar-se em relação ao espaço urbano. Na verdade, o prédio da igreja matriz foi inserido "de lado" com relação ao espaço da praça, resultando disto que o acesso preferencial, ou seja, diretamente da praça para o interior da igreja, se praticasse em sua parede lateral e não na fachada principal, como tinha sido habitual na tradição cristã desde a época de Constantino.

(...) É nossa opinião que a modalidade urbanística da igreja de lado para praça, na verdade de origem medieval, deveria entender-se como urbanismo mudéjar, pois se trata de um fenômeno aparecido na Espanha, como resultado da mistura, combinação, simbiose ou integração de elementos urbano-arquitetônicos de origem muçulmana, com outros de origem castelhana ou aragonesa. (NICOLINI, 2005, p. 32-33 - tradução nossa)

O arquiteto argentino demonstraria que, no primeiro grande século de colonização, a inusitada posição que o principal templo de inúmeras cidades assumiria em relação ao grande espaço vazio que encerraria a plaza de armas não seria um fator de exceção frente ao modos operandi comum de direcionar a fachada principal da igreja diretamente ao seu adro - de frente para a praça que se abriria contígua ao edifício religioso. A implantação das estruturas monumentais das igrejas matrizes ou das sedes episcopais com um dos seus flancos voltados para a plaza e com a fachada principal aberta para uma das ruas que atingiriam o grande espaço público, seria a regra urbanística, norma praticada na grande maioria dos assentamentos hispano-americanos (Figuras 22 e 23) - artifício que também seria constantemente empregado em outras igrejas paroquiais que se mostrariam de lado para seus adros rasgados nos diversos bairros adjacentes ao centro urbano, bem como nas igrejas dos conventos e monastérios próximos ou distantes da plaza mayor.

Na Península Ibérica, este fato estaria condicionado pelas restritas áreas destinadas às novas construções oferecidas na apertada estrutura preexistente dos núcleos urbanos 
medievais levantados acima da massa edificada das reconquistadas cidades mouriscas, bem como pela forte herança que a cultura árabe deixaria para os castelhanos e para os Aragoneses, especialmente no processo de recuperação dos territórios do sul da Espanha. Nas Américas, por sua vez, apareceria como uma transferência direta do modos operandi oriundo da fusão mudéjar entre a arte cristã e a muçulmana - transferência adaptada a uma realidade ímpar na qual as cidades surgiriam previamente planificadas, profundamente ordenadas e com uma dimensão desconhecida nos densos, fechados e circunscritos núcleos peninsulares. Ou seja, para além da imposição vertical de uma ação praticada eventualmente na Metrópole, não existiriam outras motivações para a utilização desta prática, geneticamente muçulmana, na configuração das cidades coloniais hispano-americanas.

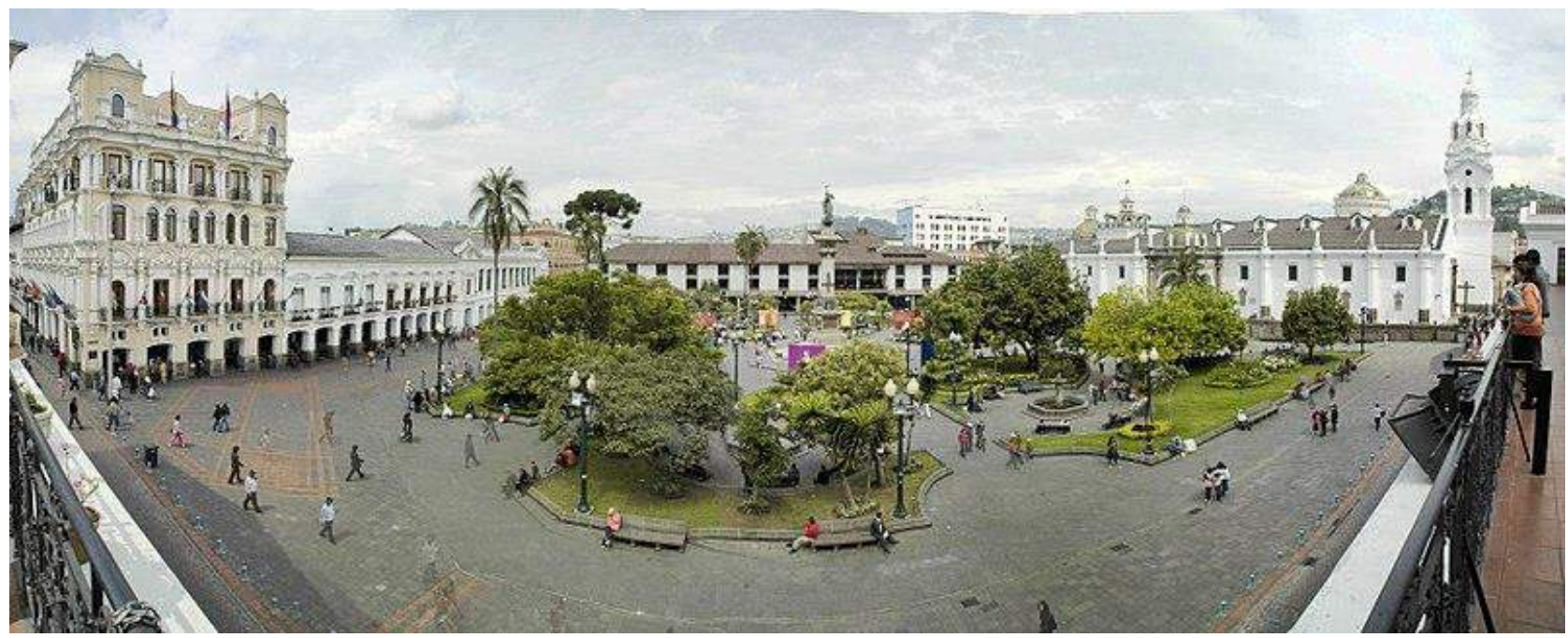

Figura 22 - Plaza Mayor de Quito. Em destaque, a Catedral Primada, construída a partir de 1557, mas em grande parte refeita após o tremor de 1660. Sua fachada lateral ocuparia todo um lado da Plaza Mayor.

Fonte: https://commons.wikimedia.org/wiki/File:Plaza Grande - Quito.jpg Acessado em 15 de novembro de 2017. Fotografia de Ángel M. Felicísimo. 


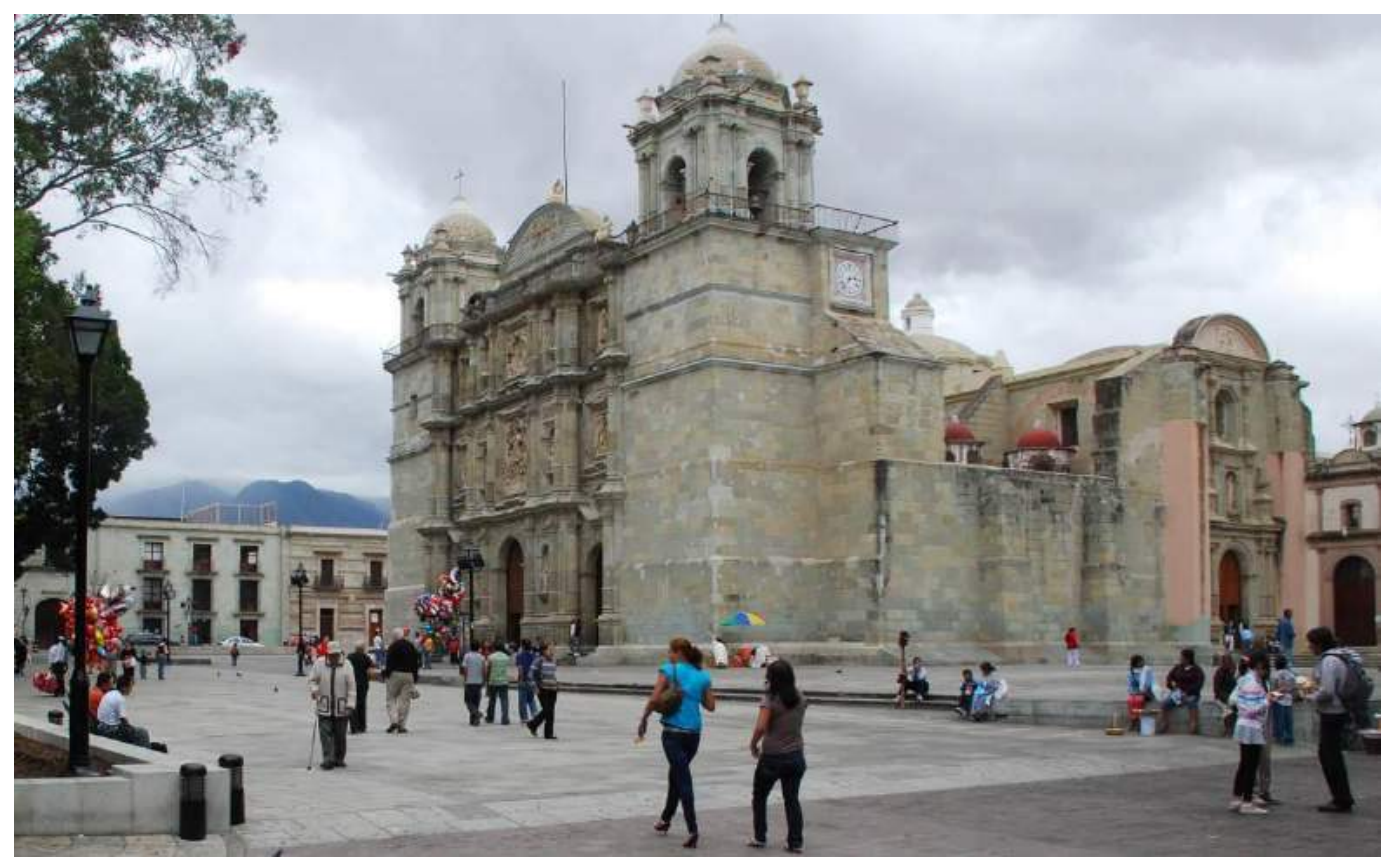

Figura 23 - Catedral de Nuestra Señora de la Asunción da antiga Antequera de Oaxaca iniciada em 1535, mas reconstruída no século XVIII após um forte sismo. Apresenta-se voltada de lado para um dos setores da Plaza de Armas.

Fonte: Fotografia do autor, 2009.

No século XVI, estas iniciativas se adaptariam perfeitamente à nova realidade urbana, principalmente à necessidade de se implantar, de forma rápida e coerente, os grandes organismos das igrejas matrizes nas nascentes plazas mayores. Seria comum que os solares reservados à construção do templo principal, desde a fundação das cidades, ocupassem toda a extensão de um dos quarteirões que conformariam o perímetro da praça o que permitiria acolher não só a igreja, mas também as estruturas de apoio que ela poderia requerer posteriormente. Deste modo, o posicionamento lógico que o templo deveria assumir em prol da ocupação da área mais privilegiada do quarteirão - que obviamente coincidiria com o alinhamento do solar voltado ao vazio da praça -, seria de lado, seguindo a tradição mudéjar. O edifício preencheria toda a testada da quadra - ou, na melhor das hipóteses, deixaria um espaço aberto à frente de sua fachada principal, um adro voltado para uma das ruas que alcançariam a plaza de armas. Uma implantação coerente para os burocráticos artifícios de assentamento que a urbanística hispano-americana imporia nos séculos de colonização, mas ineficiente no que se refere à constituição de um cenário dramático - que seria abertamente favorecido pela presença do monumental frontispício e das altas torres do templo diretamente voltados à plaza de armas.

Contudo, muitas das igrejas maiores quinhentistas, originalmente assentadas

(c) Urbana: Rev. Eletrônica Cent. Interdiscip. Estud. Cid. Campinas, SP V.10, n.1 [18] p.54-103 jan./mai. 2018 
flanqueando um dos lados do perímetro das praças principais, seriam reconstruídas algumas ainda no século XVI - assumindo diferentes locações, um tipo de implantação na qual suas fachadas principais apontariam diretamente às plazas mayores.

As catedrais das duas mais importantes cidades das Índias Ocidentais - as capitais virreinales da Nueva España e do Perú -, originalmente locadas segundo a tradição mudéjar, seriam reconstruídas após a segunda metade do século XVI ganhando nova orientação: a atual Catedral Metropolitana de la Ciudad de México (Figuras 24 e 25) seria iniciada em 1563, sob o desenho do arquiteto basco Claudio de Arciniega (1527-1593); e a nova Basílica de Lima (Fifura 26) teria seu risco reelaborado pelo arquiteto espanhol Francisco Becerra (1545-1605), em 1584. Independente da motivação que levaria os frontispícios destes edifícios a assumirem um "giro" de $90^{\circ}$ em direção à cavidade interna das plazas mayores ter nascido da nova concepção do espaço em perspectiva, que chegaria às Américas através da herança renascentista, ainda viva nos séculos XVI, XVII e XVIII (SALCEDO, 1990, p. 24), ou de ter aparecido antecipando uma clara expressão da teatralidade barroca - já que seriam alteradas precocemente, nos anos mil e quinhentos -, o fato é que estas transformações seriam essenciais para a reorientação dramática das praças em direção à retórica e à persuasão perseguidas nos séculos subsequentes.

As monumentais fachadas destas e de outras tantas sedes episcopais que passariam pelo mesmo processo de reorientação cenográfica de seu frontispício, aliadas às frontarias barrocas de outros templos e capelas que usualmente seriam construídos alinhados à fachada principal da catedral - só como exemplo poder-se-ia recordar o inebriante Sagrario levantado a partir de 1750 contíguo à face oeste da Catedral do México, pelo arquiteto espanhol Lorenzo Rodríguez (1704-1774) -, protagonizariam não só o espetáculo dramático das plazas mayores, mas toda apreensão do cenário das cidades. 


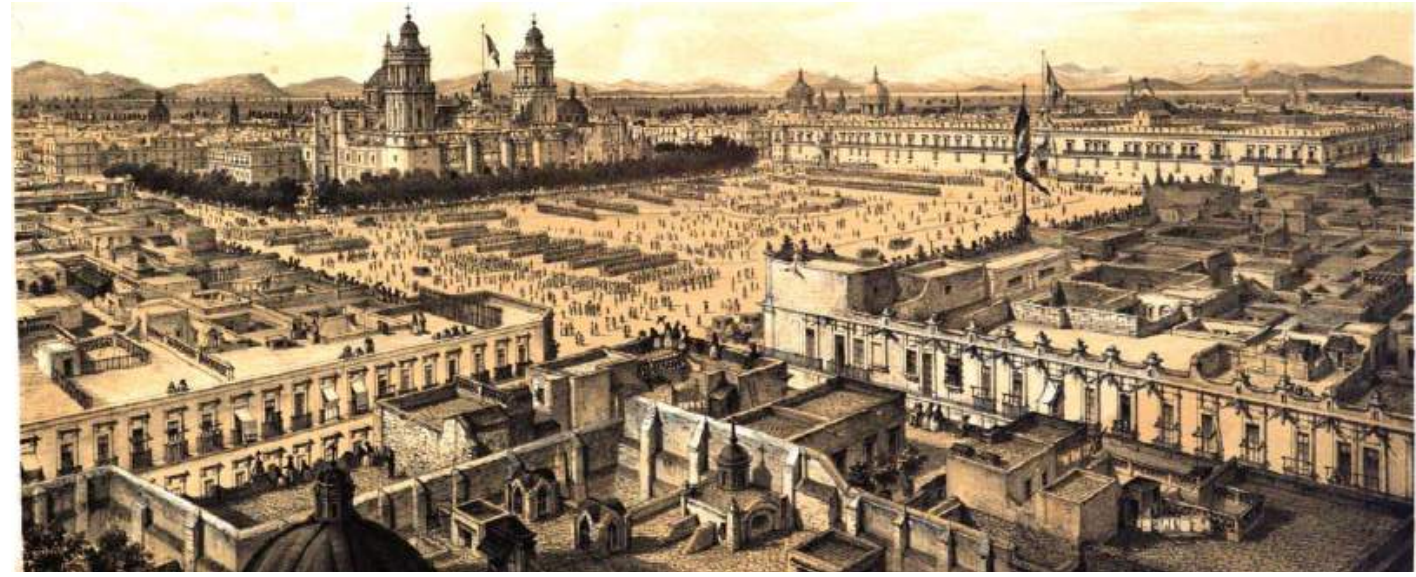

Figura 24 - Plaza de Armas de México. Litografia do pintor e gravurista mexicano, Casimiro de Castro, publicada em 1855. Em destaque, a monumental Catedral Metropolitana. Fonte: DECAEN (1855, p. 5).
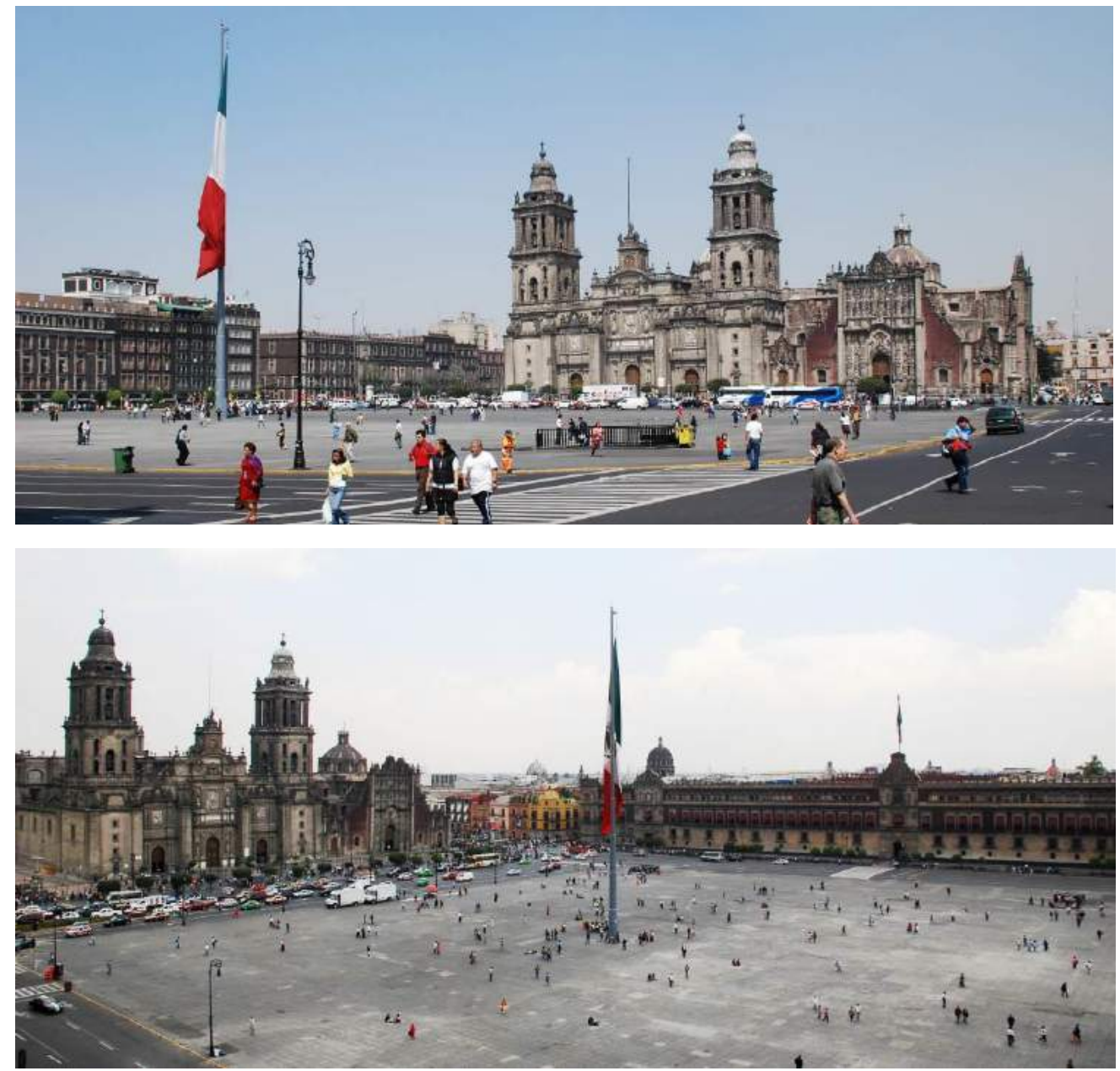

Figura 25 - Panoramas da Plaza Mayor (também conhecida como El Zócalo) da Cidade do México, com destaque para a Catedral voltada de frente à praça. Fonte: Fotografias do autor, 2009. 


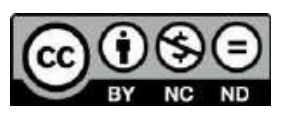

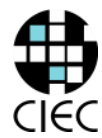

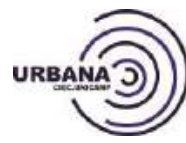

DOI: $10.20396 /$ urbana.v10i1.8651022

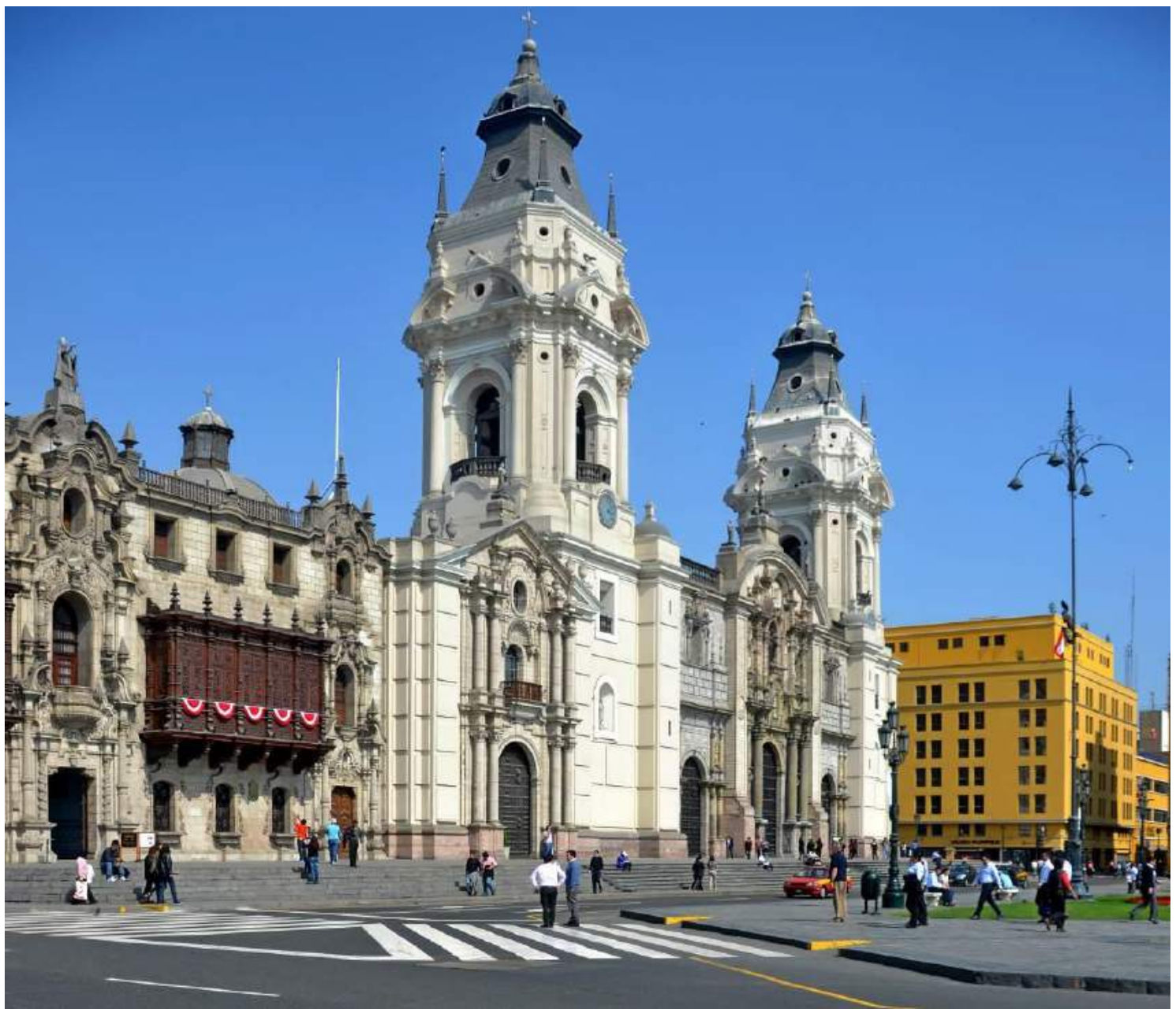

Figura 26 - Catedral de Lima, voltada de frente à Plaza de Armas.

Fonte: Fotografia do autor, 2015.

\section{A arquitetura religiosa como protagonista na transfiguração da paisagem urbana das cidades hispano-americanas no século XVIII}

Paradoxalmente, a rígida e monótona trama viária da maioria das cidades hispanoamericanas serviria para destacar, por oposição "figura-fundo", expressivos acontecimentos arquitetônicos que seriam levantados nos domínios dos assentamentos coloniais. Ou seja, os núcleos urbanos regulares poderiam conformar cenários barrocos devido à contaminação do seu ambiente estéril por eventos profundamente cativantes gerados pela influência que a arquitetura exerceria nas imagens capturadas no seio da cidade, "costuradas" na dimensão espaço-temporal da apreensão do espaço urbano.

Acompanhando a importância que as catedrais - reorientadas e remodeladas a partir da segunda metade do século XVI - assumiriam como agentes prioritários na constituição dramática das plazas mayores, seria possível afirmar, por extensão, que os edifícios

(c) Urbana: Rev. Eletrônica Cent. Interdiscip. Estud. Cid. Campinas, SP v.10, n.1 [18] p.54-103 jan./mai. 2018 
eclesiásticos, especialmente as igrejas, seriam os elementos arquitetônicos que ganhariam o maior destaque nos núcleos virreinales durante o século XVIII.

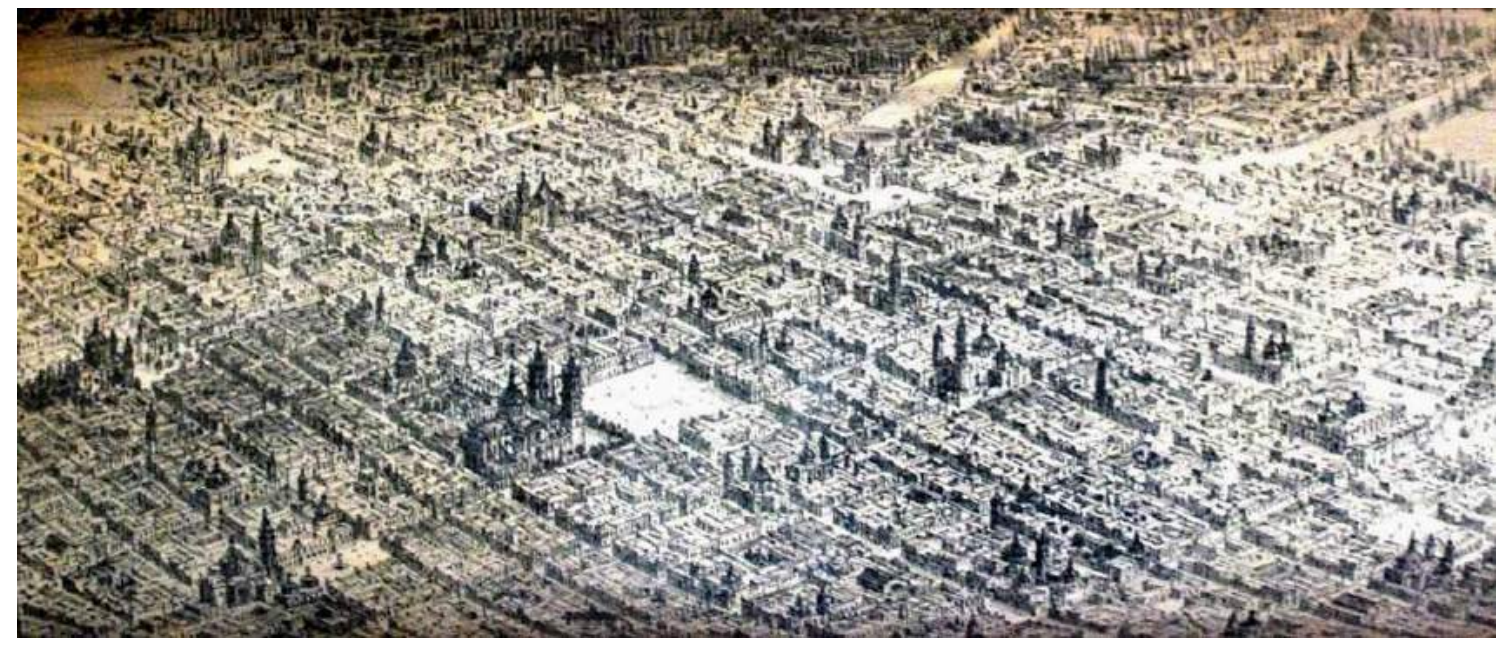

Figura 27 - Detalhe da vista panorâmica da Cidade do México - confeccionada por Casimiro Castro em meados do século XIX. Vislumbra-se a imensa Catedral assentada no colossal vazio da Plaza de Armas, assim como a grande quantidade de igrejas, com suas torres e cúpulas despontando como "figuras" no "fundo" regular da massa edificada na grelha ortogonal.

Fonte: Fotografia do autor, 2009. Imagem retirada do estofado de uma poltrona oitocentista pertencente ao acervo do Museo de la Ciudad de México.

Na verdade, a conversão, catequese, divulgação e consolidação da fé católica em território americano seria a mais grandiosa empresa praticada pelos espanhóis após a conquista do território das Índias Ocidentais. A inserção, frequentemente dramática, dos edifícios eclesiásticos em tecidos urbanos comandados por um design de teor supostamente institucional - uma trama viária regular que poderia representar o desejo utópico de constituição de uma sociedade racionalizada e ordenada nos domínios peninsulares (RAMA, 1998 , p. 20) - revelaria a essencial e prioritária componente cristã lançada às intricadas ações do ato civilizatório da inóspita região. Deste modo, no século XVIII, sob o signo da fé católica, as igrejas seriam os organismos arquitetônicos que contagiariam simbolicamente os espaços adjacentes - e por somatória, todo contexto da cidade - transformando o rígido ambiente urbano quadricular em um espaço com forte e dominante componente espiritual.

Como contrapontos verticais, volumétricos e decorativos, destacados em relação à horizontalidade e à previsibilidade reinantes, os edifícios eclesiásticos assumiriam um papel proeminente, nem mesmo ameaçado pelos mais importantes edifícios e espaços ligados ao poder da metrópole espanhola - e mesmo o ambiente, voltado, efetivamente, à exaltação da força do Estado, seria dominado pela imponente estrutura da catedral, como foi visto.

(c) Urbana: Rev. Eletrônica Cent. Interdiscip. Estud. Cid. Campinas, SP V.10, n.1 [18] p.54-103 jan./mai. 2018 
Neste sentido, a rígida estrutura viária preexistente acabaria favorecendo a busca por expressões arquitetônicas que pudessem destacar os edifícios religiosos na extensa e repetitiva superfície da grelha - e aqui entraria uma das maiores contribuições barrocas à conformação da paisagem urbana transfigurada no século XVIII. De fato, grande parte das construções religiosas que se espalhariam pelos núcleos urbanos já teria sido erigida no século XVI seguindo aqueles preceitos debatidos para sua implantação - normalmente contando com um pequeno recuo aberto para dentro do quarteirão, espaço conquistado na manzana deslocando a igreja do alinhamento das construções ordinárias, para conformar, deste modo, seu adro e marcar sua condição hierarquicamente superior. Contudo, o realce dos edifícios religiosos não poderia ser comandado apenas pelas suas modestas inserções urbanísticas. Notadamente, a estrutura dramática perseguida seria alcançada através das intervenções que as igrejas sofreriam durante o período barroco.

O edifício e, consequentemente, a cidade, seriam acentuados por torres e cúpulas muitas remanescentes do século XVI, outras remodeladas ou construídas segundo a poética do Barroco (Figura 27). Os campanários, nem sempre altos devido aos riscos de terremotos, mas invariavelmente fortes e sólidos, em congruência com as calotas onduladas hemisféricas que se sucederiam nos fechamentos das coberturas, apontariam como essenciais contrapontos verticais frente à reinante superfície horizontal e monótona das quadras que se sucederiam na tradicional cidade regular. Além do mais, os contornos exteriores das construções, formados, para além das torres e cúpulas, pelas terminações superiores dos frontispícios e das fachadas laterais dos templos, provocariam a valorização das silhuetas como componentes arquitetônicos dramáticos que despertariam a atenção do espectador (Figuras 28 e 29).

(c) Urbana: Rev. Eletrônica Cent. Interdiscip. Estud. Cid. Campinas, SP v.10, n.1 [18] p.54-103 jan./mai. 2018 

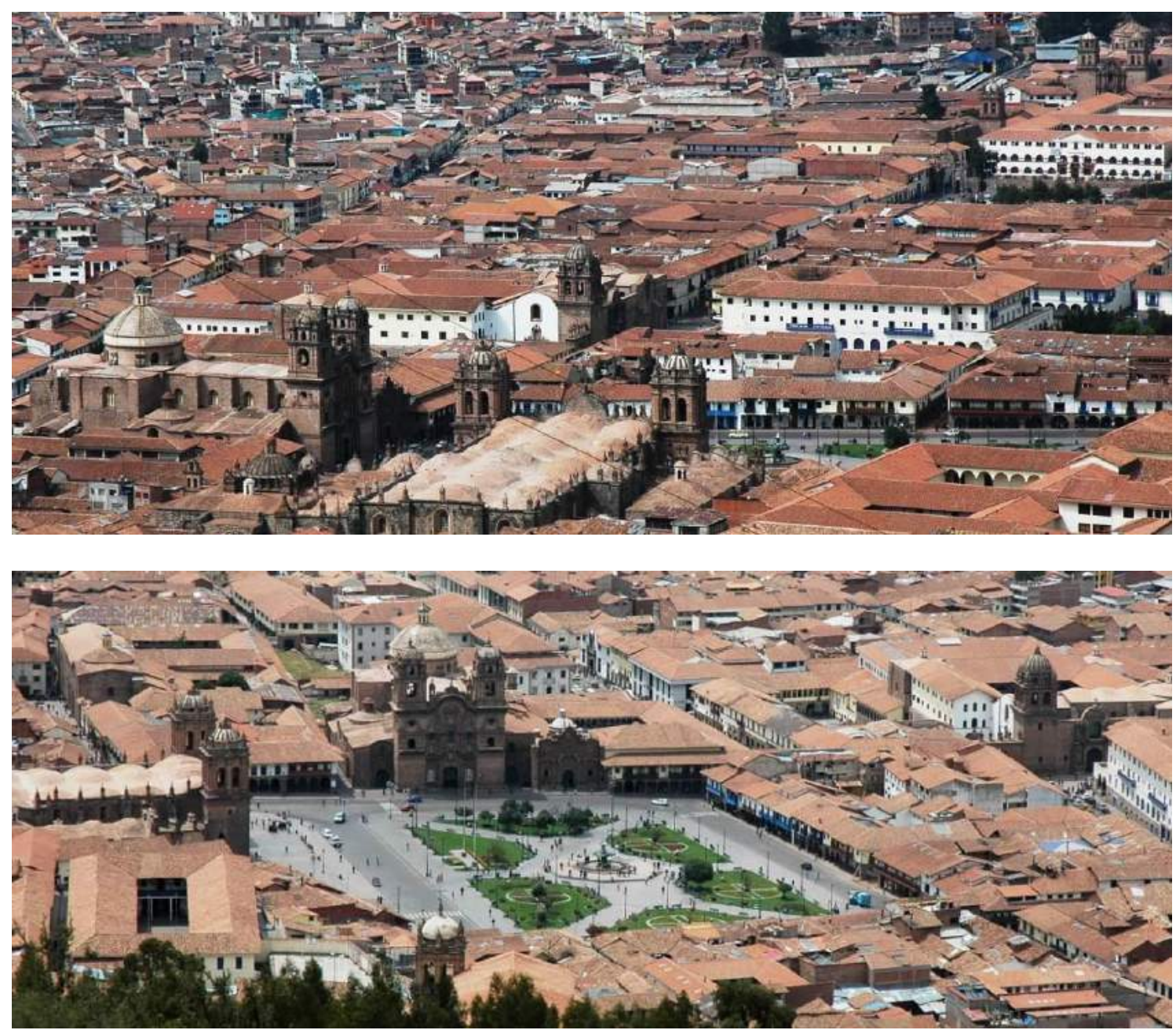

Figura 28 - Panoramas da cidade de Cusco (Peru). Em destaque, as torres e as cúpulas das principais igrejas em contraste com a massa homogênea das construções ordinárias. Em primeiro plano, na Plaza de Armas, a Catedral e a Igreja de La Compañia. Fonte: Fotografias do autor, 2007. 


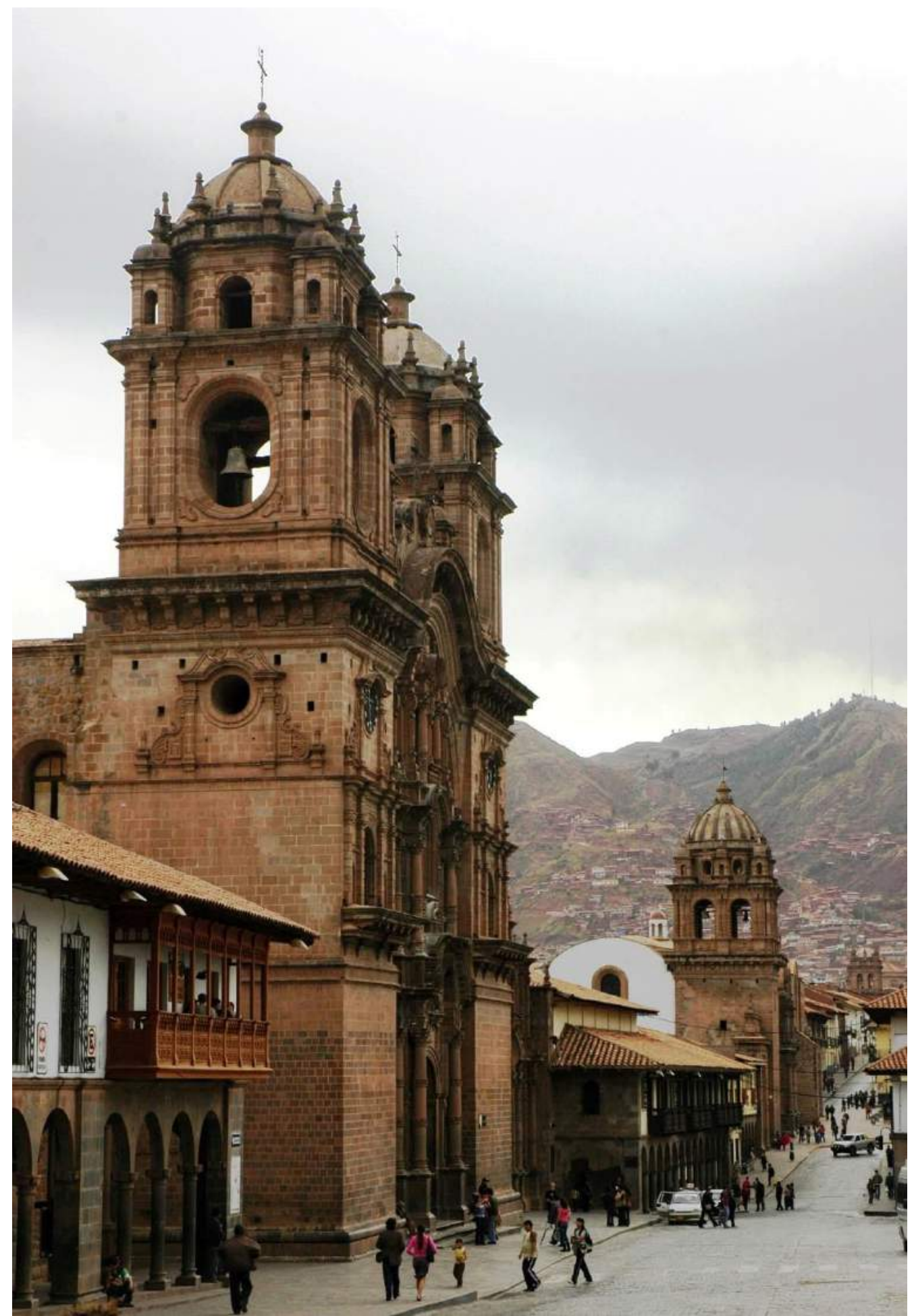

Figura 29 - O eixo retilíneo da "Via Sacra", que corta a cidade de Cusco, visto a partir da Plaza de Armas - que se abre à direita. É possível apreciar, em escorço, as torres e a fachada de La Compañia, além dos campanários de La Merced e de Santa Clara. Fonte: Fotografia do autor, 2007. 


\section{O poder da ornamentação e as fachadas-retábulo}

Os maiores recursos dramáicos justapostos às igrejas, influenciando diretamente a paisagem urbana de algumas cidades coloniais, seria a decoração efusiva aplicada em suas superfícies: adornos lançados nos arremates das torres, nas portadas, mas principalmente nos núcleos centrais dos frontispícios - produzindo o recurso primordial das fachadas-retábulo.

Muitas das elevações principais e laterais das capelas, igrejas e catedrais, evoluiriam para a condição superior de armações cenográficas que acomodariam legítimos retábulos a céu aberto: mais do que portadas ornamentadas que anunciariam o acesso longitudinal ou transversal ao templo, as fachadas-retábulos se configurariam como complexos frontispícios que se apresentariam como altares espalhados pela cidade, levando os átrios, as praças e as ruas que se disporiam à frente, a se comportarem como projeções exteriores das naves internas das igrejas. Para Chueca Goitia:

As fachadas de muitas igrejas da América são altares colocados na rua. Não é uma ocorrência incomum, porque na Espanha logo se espalhou, sobretudo na arte isabelina e no barroco, o desejo levar os retábulos para o lado de fora. Mas o que na Espanha se fez com alguma prudência e hierarquia, nesta super-Espanha, foi feito sem qualquer contenção, despojando-se de todo preconceito. E se fez, para além da razão de se impor externamente, por outra motivação de que não se tem reparado, e que me parece fundamental: é que o espaço sagrado no templo americano não é tanto o que está dentro como o que está fora. (CHUECA GOITIA, 1980, p. 191 - tradução nossa)

Mais que um poderoso artifício da cenografia urbana barroca, as fachadas-retábulo promoveriam uma aproximação entre as soluções quinhentistas, preparadas para auxiliar a conversão e a catequese dos indígenas nas zonas rurais espalhadas pelas Índias Ocidentais, e o papel que as capitais e os centros regionais deveriam assumir como ambientes propagadores da fé católica. Ou seja, voltadas para os núcleos como altares distribuídos pelas ruas e praças - "derramadas" nos espaços abertos onde circulariam a grande massa dos indivíduos -, expressariam a necessidade barroca de sacralizar o espaço urbano, transformando as cidades coloniais em grandes teatros da expressão católica e da intensa propaganda religiosa.

Contudo, à diferença das soluções quinhentistas, o traslado simbólico do altar-mor de dentro para fora da igreja não significaria uma ação de relocação das celebrações e da condução dos ofícios religiosos para o ambiente exterior - como aconteceria nos grandes complexos eclesiásticos, direcionados aos nativos, construídos em áreas rurais da América hispânica durante o século XVI. Na verdade, a cultura barroca já seria capaz de absorver a 
simples sugestão virtual da transferência do espaço interno da igreja para fora de seus domínios - para o ambiente urbano contíguo. A exibição dos altares de pedra nas fachadas eclesiásticas - frontispícios ultra adornados, articulados coerentemente com as torres, portadas, coberturas e volumes do edifício - já bastaria para produzir o sentido da emanação da fervorosa religiosidade católica ao espaço urbano: o contágio espiritual do contexto citadino pelos altares projetados desde a cavidade interna do templo - pura expressão da persuasão religiosa e do teatro barroco (Figuras 30 e 31).

Para além destes eficientes artifícios retóricos de propaganda, a fachada-retábulo agiria como uma espécie de elemento de transição que anteciparia os espaços efetivos de culto que se abririam no interior dos templos, ambientes hipnóticos articulados com a profusa ornamentação dourada típica das igrejas barrocas ibéricas. Sobre certos aspectos, seria produzido um coerente mecanismo no qual a fachada da igreja, com seu exuberante altar exterior, anunciaria a presença do edifício sagrado e convocaria os fiéis para ingressarem em seus domínios - espaço interno que, conformado pelo reluzente e escuro ambiente da caverna de ouro, representaria o encontro íntimo do crente com o seu Deus (BAYÓN, 1974, p. 147).

Poder-se-ia dizer que o interior da igreja daria continuidade às ações cenográficas que surgiriam na cidade, se configurando como uma extensão do espaço urbano; o ato de irromper no ambiente sagrado da nave e se surpreender com sua majestosa cavidade ornamentada faria parte indissociável da experimentação do enredo da cidade barroca (Figura 32). 


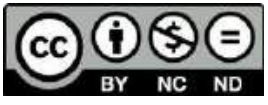
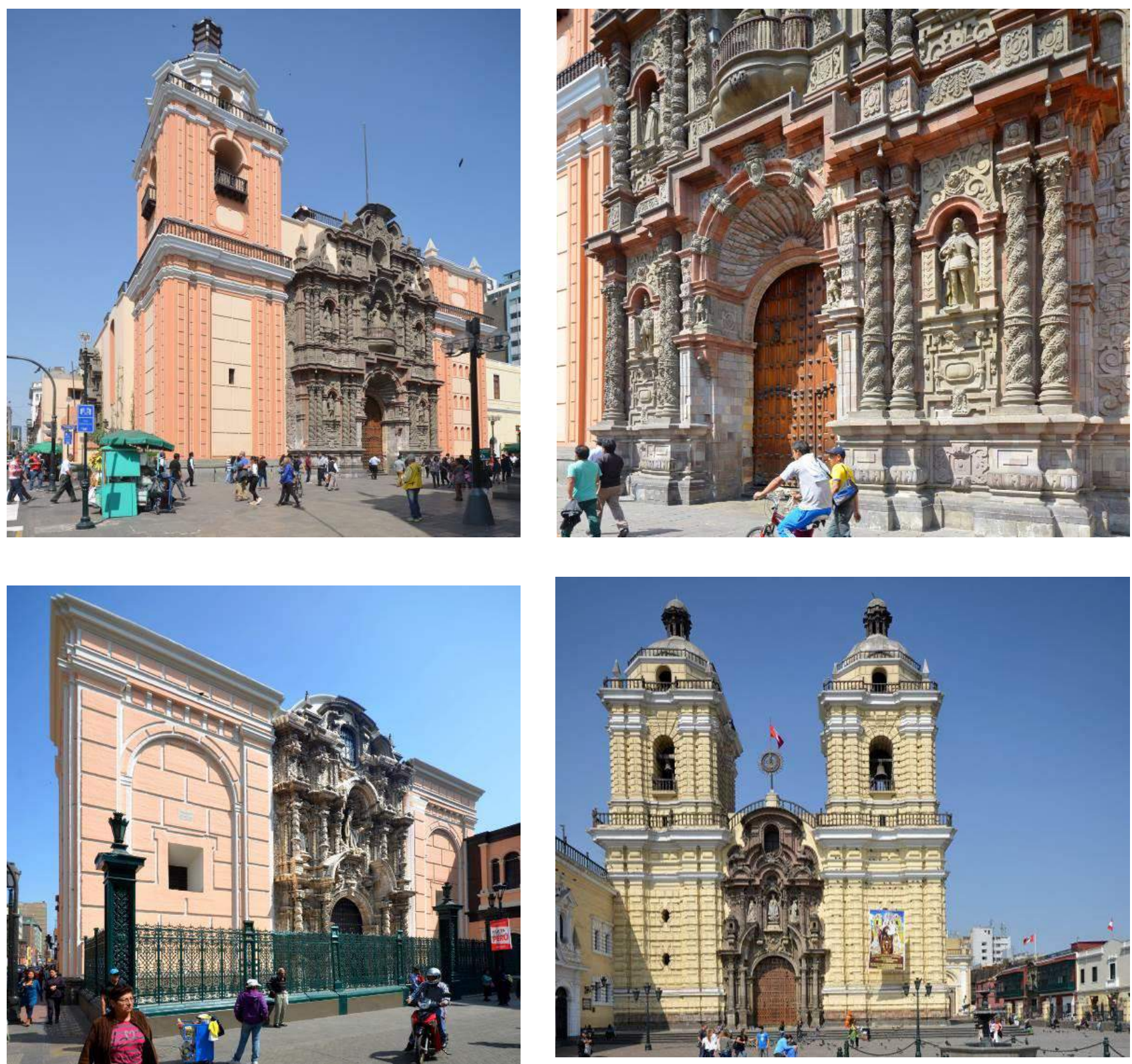

Figura 30 - Fachadas-retábulo de igrejas barrocas no centro histórico da cidade de Lima: Igreja de La Merced; detalhe do frontispício de La Merced; San Agustín; San Francisco. Fonte: Fotografias do autor, 2015. 

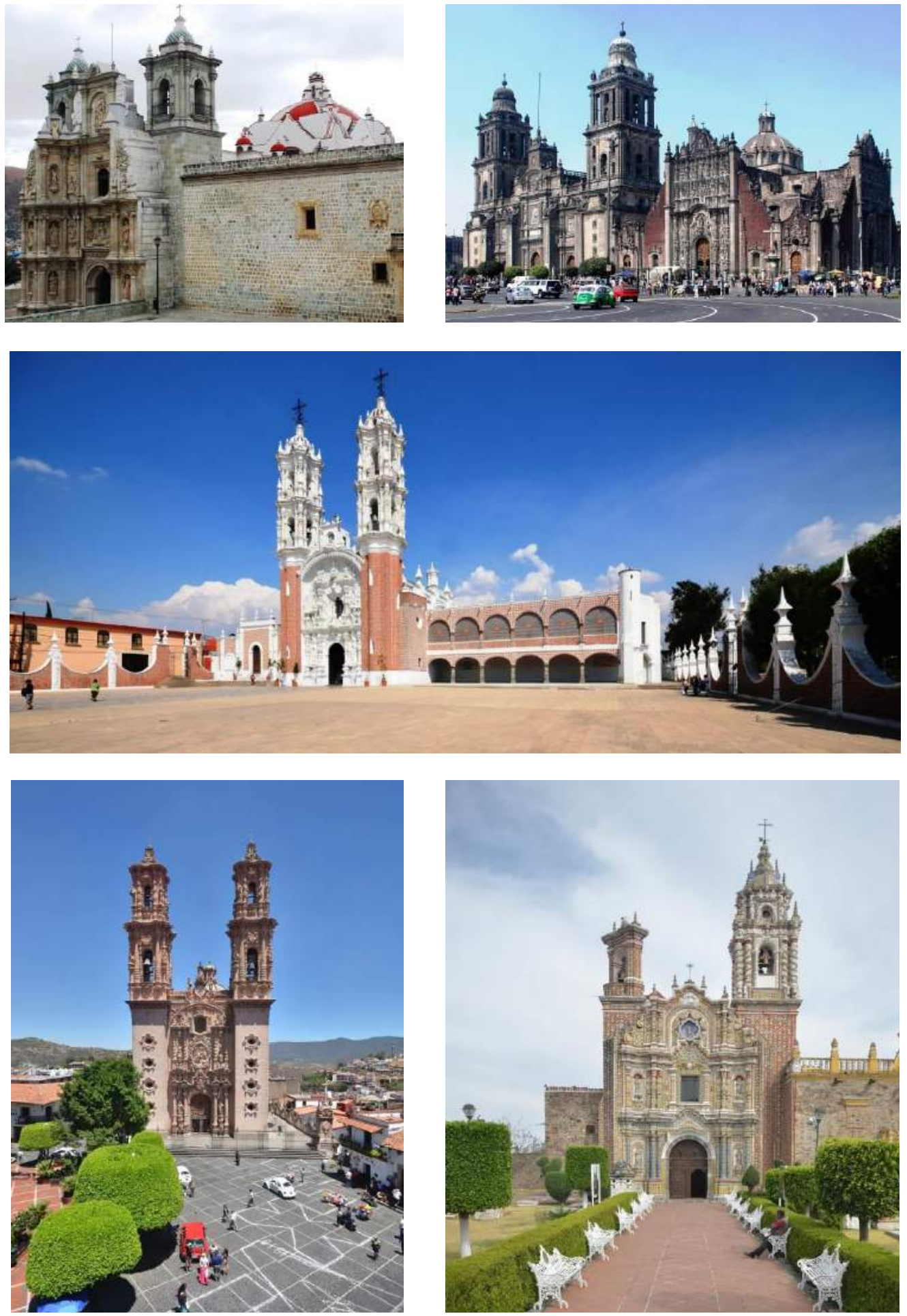

Figura 31 - Fachadas-retábulo de igrejas barrocas em diversas cidades do México: Basílica de Nuestra Señora de la Soledad (Oaxaca); Catedral e Sagrario Metropolitano (Cidade do México); Santuário de Ocotlán (Tlaxcala); Igreja de Santa Prisca (Taxco); Igreja de San Francisco de Acatepec (Cholula).

Fonte: Fotografias do autor, 2013. 

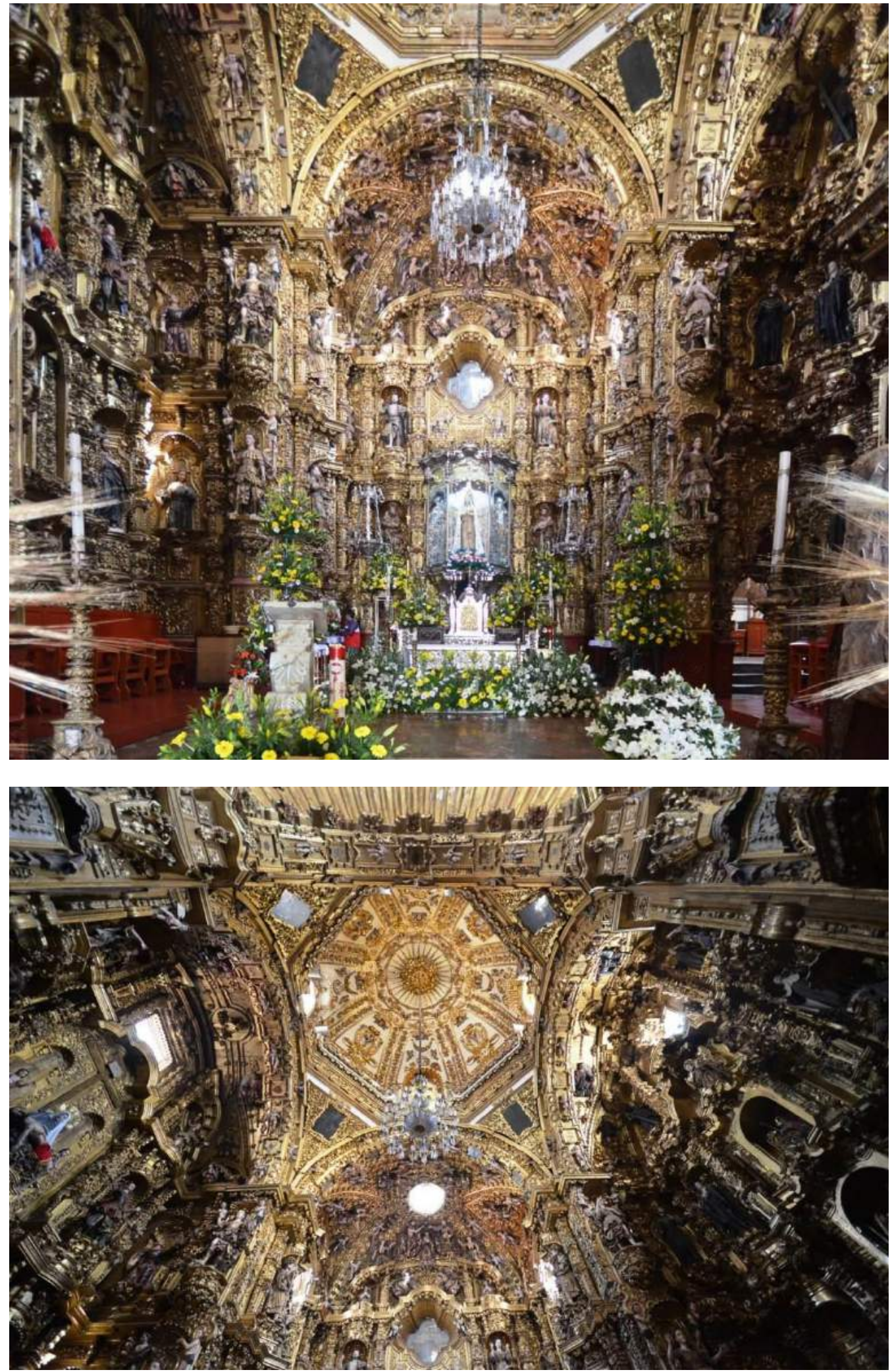

Figura 32 - Interior da Igreja do Santuário de Ocotlán, em Tlaxcala. Fonte: Fotografias do autor, 2013. 


\section{Referências}

ALLENDE CARRERA, Arnulfo. Puebla. Y el Paseo de San Francisco. Madrid: Turner, 2006.

BAYÓN, Damián. Sociedad y arquitectura sudamericana. Una lectura polémica. Barcelona: Gustavo Gili, 1974.

DECAEN. México y sus alrededores. México: Estabelecimiento litográfico de Decaen, Editor, 1855.

CHUECA GOITIA, Fernando. El Barroco hispánico y sus invariantes. In: MINARDI, Vittorio (org.). Simposio internazionale sul Barocco Latino Americano. Atti. Roma: Istituto Italo-Latino Americano, v. 1, p. 189-200, 1980.

CHUECA GOITIA, Fernando; TORRES BALBÁS, Leopoldo. Planos de ciudades Iberoamericanas y Filipinas. Madrid: Instituto de Estudios de Administración Local, 1981.

ESCUDERO ALBORNOZ, Ximena. Iglesias y conventos de Quito antiguo. Guía para visitar los principales conjuntos religiosos. Quito: Ediciones Trama, 2006.

FAGIOLO, Marcello. La fondazione delle città latino-americane. Gli archetipi della Giustizia e della Fede. In: Psicon. Rivista Internazionale di Architettura. América Latina: le città coloniali. Firenze: Psicon, Centro Studi Architettura Ouro boros, n. 5, p. 34-58, 1975.

GUTIÉRREZ, Ramón. Aproximaciones al Barroco hispanoamericano en Sudamérica. In: GUTIÉRREZ, Ramón (org). Baroco Iberoamericano. De los Andes a las Pampas. Barcelona: Lunwerg, 1997.

LUCENA GIRALDO, Manuel. A los cuatro vientos. Las ciudades de la América Hispánica. Madrid: Fundación Carolina, 2006.

MATTOS-CARDENAS, Leonardo. Ideología barroca e praxís urbanística en la América española (secc. XVII-XVIII). In: Storia della Città. Rivista internazionale di storia urbana e territoriale. Milano: Electa Periodici, n. 28, p. 59-69, 1984.

MATTOS-CARDENAS, Leonardo. Urbanismo Andino e Hispano Americano. Ideas y Realizaciones (1530-1830). Lima: FAUA, 2004.

NICOLINI, Alberto. La ciudad hispanoamericana en los siglos XVII y XVIII. In: ARANDA, Ana María (et al). Barroco Iberoamericano: territorio, arte, espacio y sociedad. Sevilla: Ediciones Giralda, v. 2, p. 1085-1100, 2001.

NICOLINI, Alberto. La ciudad hispanoamericana, medieval, renascentista y americana. In: Atrio. Revista de Historia del Arte. Sevilla: Universidad Pablo de Olavide, n. 10-11, p. 27-36, 2005.

NICOLINI, Alberto. La traza de las ciudades hispanoamericanas en el siglo XVI. In: Anales del Instituto de Arte Americano e Investigaciones Estéticas. Buenos Aires: Facultad de Arquitectura, Diseño y Urbanismo de la Universidad de Buenos Aires, 1997.

RAMA, Angel. La ciudad letrada. Montevideo: Arca, 1998. 
ROJAS MIX, Miguel. La Plaza Mayor. El Urbanismo, instrumento de dominio colonial. La Plata: Universidad Nacional de La Plata, 2006.

ROMERO, José Luis. Latinoamérica: la ciudad y las ideas. Buenos Aires: Siglo XXI Editores Argentina, 2007.

ROSSI, Aldo. L'architettura della città. Torino: Città Studi Edizioni, 2006.

SALCEDO, Jaime. El modelo urbano aplicado a la América Española: su génesis y desarrollo teórico práctico. In: Estudios sobre urbanismo iberoamericano: siglos XVI al XVIII. Sevilla: Junta de Andalucia, 1990.

VAN DOESBURG, Sebastián. 475 años de la fundación de Oaxaca. Oaxaca: Ayuntamiento de la Ciudad de Oaxaca, 2007. 2 v. 